\title{
Transcription Factors Controlling Primary and Secondary Metabolism in Filamentous Fungi: The $\beta$-Lactam Paradigm
}

\author{
Carlos García-Estrada ${ }^{1, *}$, Rebeca Domínguez-Santos ${ }^{1,2}$, Katarina Kosalková ${ }^{1}$ and \\ Juan-Francisco Martín 2,* \\ 1 INBIOTEC, Instituto de Biotecnología de León, Avda. Real No. 1, Parque Científico de León, \\ 24006 León, Spain; Rebeca.Dominguez@uv.es (R.D.-S.); kkos@unileon.es (K.K.) \\ 2 Área de Microbiología, Departamento de Biología Molecular, Universidad de León, \\ Campus de Vegazana s/n, 24071 León, Spain \\ * Correspondence: carlos.garcia@inbiotec.com (C.G.-E.); jf.martin@unileon.es (J.-F.M.); \\ Tel.: +34-987210308 (C.G.-E.); Fax: +34-987210388 (C.G.-E.)
}

Received: 3 April 2018; Accepted: 15 June 2018; Published: 19 June 2018

\begin{abstract}
Transcription factors are key regulatory proteins in all living beings. In fungi, transcription factors include either broad-domain regulatory proteins that affect the expression of many genes involved in biosynthetic processes, or proteins encoded by cluster-associated (also called pathway-specific) regulatory genes. Belonging to the most interesting transcription factors in fungi are binuclear zinc finger proteins. In addition to the transcription factors in the strict sense, other proteins play a very important role in the expression of genes for primary and secondary metabolism in fungi, such as winged helix regulators, the LaeA protein and the velvet complex. LaeA appears to be involved in heterochromatin reorganization, and the velvet complex proteins, which are nuclear factors that associate with LaeA, also have a determining role in both differentiation (sporulation) and secondary metabolite biosynthesis. The genes involved in the biosynthesis of $\beta$-lactam antibiotics are well known and serve as an excellent model to understand the transcriptional control of genes involved in the biosynthesis of secondary metabolites. Interaction between different regulatory proteins in the promoter regions may represent a cross-talk regulation between different gene clusters.
\end{abstract}

Keywords: $\beta$-lactam antibiotics; control of gene expression; filamentous fungi; regulation; secondary metabolism; transcription factors

\section{Introduction}

Fungi play very important roles in nature. They are crucial in biotransformation in the biosphere, thus acting as recyclers and playing a major role in the balance of ecosystems. Wood-decay fungi (mainly basidiomycetes) are classified as brown (e.g., Serpula lacrymans), soft (e.g., Chaetomium globosoum), and white (e.g., Pleurotus ostreatus) rot fungi, and participate in the degradation of renewable wood sources and decomposition of organic matter, thus providing a large amount of resources for the microbial world [1,2]. Fungi are normally not pathogenic organisms, although some species may infect plant and animal tissues and cause notable diseases. Certain fungi can be found living in association with different plants, stablishing various levels of interaction, from mutualism to obligate parasitism. Plant-fungal interactions have a strong influence in the biosynthesis and secretion of secondary metabolites. Therefore, characterization of the transcription factors that control the expression of fungal genes is of great importance to understand the plant-fungi interactions $[3,4]$. Also, it is important to note that filamentous fungi are the closest eukaryote organisms to the metazoan and therefore, they serve as an excellent model to understand the basic mechanisms that control 
gene expression in higher eukaryotes. Indeed, yeasts and filamentous fungi have served in the last decades as true models to understand the basic biology of eukaryotes, which has contributed to pave the way for research in areas such as genetics, physiology, medicine, and cell biology. For example, Saccharomyces cerevisiae, baker's yeast, has been used as a model to study aging, regulation of gene expression, signal transduction, cell cycle, metabolism, apoptosis, neurodegenerative disorders, and many other biological processes [5]. This yeast was used to set up the basis to discover the key regulators of the eukaryotic cell cycle, a research that led Leland H. Hartwell, R. Timothy Hunt, and Paul M. Nurse to be awarded the Nobel Prize in Medicine in 2001.

On the other hand, filamentous fungi and yeasts (Ascomycetes mainly from the genera Penicillium, Aspergillus, Saccharomyces and Kluyveromyces) contribute to the maturation processes of cheese and other fermented products for the food industry. Other Ascomycetes play a key role in the pharmaceutical industry as producers of secondary metabolites, such as antibiotics (e.g., Penicillium chrysogenum, Acremonium chrysogenum), antitumorals (Taxomyces andreanae), anticholesterolemics (Aspergillus terreus, Penicillium brevicompactum) and immunomodulators (Penicillium stoloniferum, Tolypocladium niveum) [6-8].

Basic studies on fungal physiology were first carried out in Aspergillus nidulans and Neurospora crassa and soon after they were extended to P. chrysogenum. The complete genome of this filamentous fungus was sequenced at the end of the last decade [9], thus paving the way to different transcriptomics, proteomics, and metabolomics studies. Therefore, a vast amount of information has been gathered on different molecular aspects in P. chrysogenum, which together with the large number of molecular tools that have been developed in this microorganism for biotechnological purposes, have made this fungus extremely interesting as a model of fungal physiology and biotechnology.

Due to the interest of $P$. chrysogenum for the pharmaceutical industry as $\beta$-lactam producer, most of the research carried out on this fungus has been focused on aspects related to penicillin biosynthesis and production. As a consequence, the benzylpenicillin biosynthetic pathway is one of the best characterized processes from the genetic, biochemical, subcellular, and metabolic points of view and therefore, it can be considered a paradigm of the compartmentalized biosynthetic pathway for the study of fungal secondary metabolites biosynthesis. A special emphasis has been given to the study of the transcription factors in P. chrysogenum, which has provided strong evidence of the complex regulatory networks controlling growth, differentiation, and secondary metabolite biosynthesis $[10,11]$.

Secondary metabolism genes are often clustered in filamentous fungi. The biosynthesis of secondary metabolites is a complex process coupled with morphological development, since most secondary metabolites are produced when the fungus is beginning a stage of development represented by the formation of spores and after the initial growth phase has been completed [10]. Transcriptional control of genes involved in the biosynthesis of secondary metabolites is carried out by two categories of transcription factors that interact with distinct recognition sequences (target sequences) present in the promoter regions of different genes. These transcription factors can be regulatory proteins that are specific to a particular gene cluster, or broad-domain transcription factors that are mediated by nutritional and environmental signals such as carbon source, $\mathrm{pH}$, or nitrogen sources. Therefore, control of secondary metabolism is subjected to complex regulatory networks that ensure the biosynthesis of secondary metabolites in response to general cellular metabolism and to the presence of specific pathway inducers [11].

One of the best characterized fungal secondary metabolism pathways is the biosynthesis of $\beta$-lactam antibiotics. Hydrophobic penicillins are synthesized by P. chrysogenum, Aspergillus nidulans, and other Penicillium and Aspergillus species [12], whereas A. chrysogenum is able to produce hidrophilic penicillins and cephalosporin $C$. The hydrophobic or hydrophilic nature of different penicillins is conferred by the side chain that is attached to the penam nucleus, which comprises the $\beta$-lactam ring fused to a 5-membered thiazolidine ring. Penicillin and cephalosporin $C$ share the initial steps of their respective biosynthetic pathways [13]. The $p c b A B$ and $p c b C$ genes, which show a divergent orientation and share a bidirectional promoter, code the enzymes necessary for the biosynthesis of isopenicillin 
$\mathrm{N}$, the latter representing the branching point for the biosynthesis of hydrophobic penicillins and cephalosporin C [13].

In $P$. chrysogenum and $A$. nidulans, isopenicillin $\mathrm{N}$ is converted to hydrophobic penicillins (e.g., benzylpenicillin) by means of the $p e n D E$-encoded acyltransferase. The $p c b C-p c b A B$ genes are always grouped and are located next to the penDE gene [13].

Cephalosporin $\mathrm{C}$ biosynthesis in A. chrysogenum requires the epimerization of isopenicillin $\mathrm{N}$ to penicillin $\mathrm{N}$ in a reaction catalyzed by the products of the cefD1 and cefD2 genes. This is followed by thiazolidine ring expansion and further hydroxylation by means of the bifunctional protein encoded by the cefEF gene. The last step in cephalosporin $C$ biosynthesis consists of an acetylation reaction catalyzed by the product of the $c e f G$ gene. These genes are organized in at least two clusters located on different chromosomes. The "early" gene cluster, located on chromosome VII (4.6 Mb), contains pcbAB, $p c b C$, cefD1, and cefD2 genes. The "late" gene cluster, located on the 2.2-Mb chromosome I, includes the cefEF and cefG genes [13].

The promoter regions of these genes contain target sequences for many different types of transcription factors. The penicillin biosynthetic gene cluster represents a good example of the complexity of interactions between promoter regions and transcription factors (Figure 1). These regulators control the expression of secondary metabolism genes in response to different nutritional, environmental and stress conditions and some of them are described in the following sections.

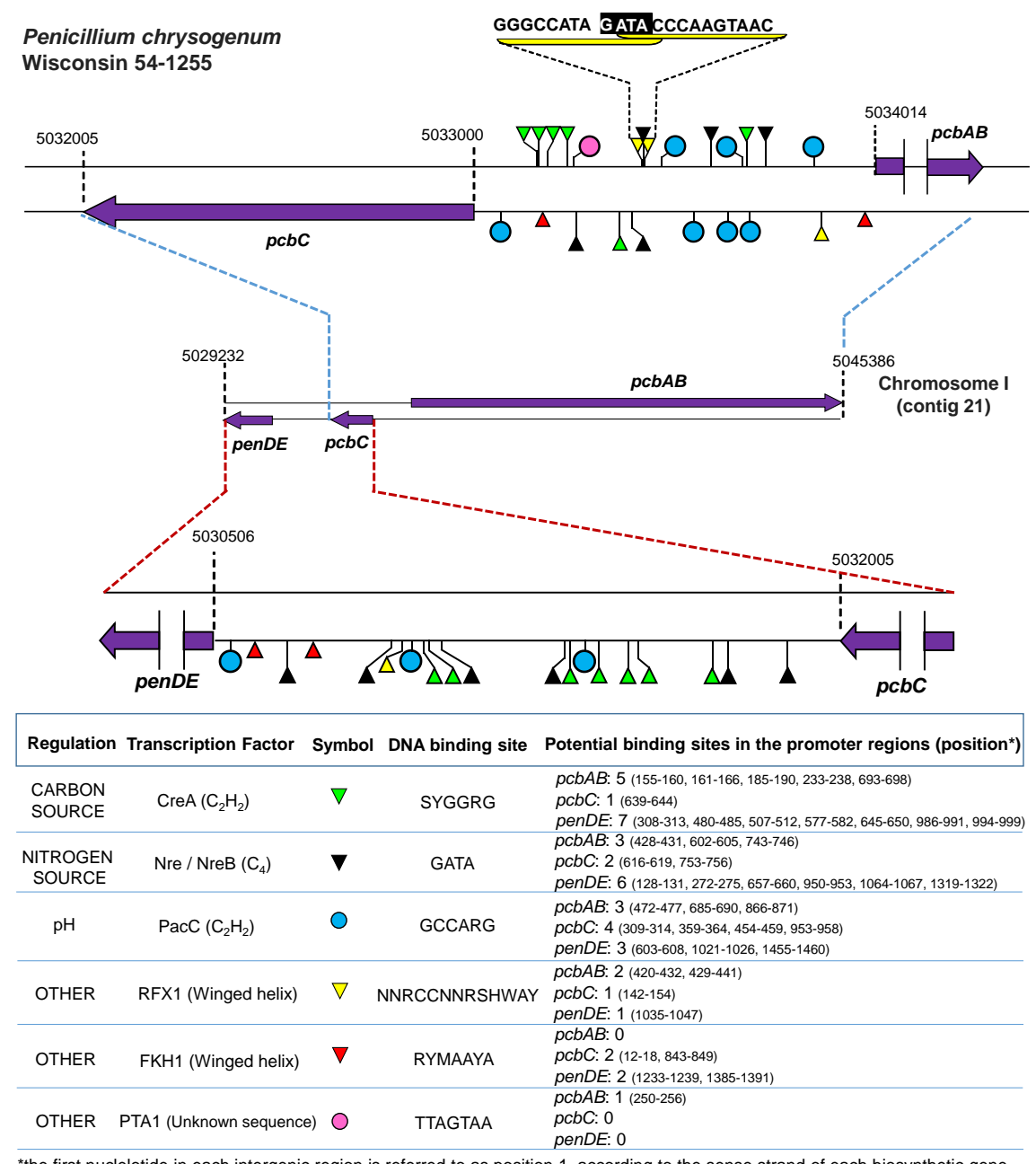

Figure 1. Schematic representation of the promoter regions of the benzylpenicillin gene cluster and potential binding sites for some transcription factors. Numbers above genes indicate positions within contig 21 of the P. chrysogenum Wisconsin 54-1255 genome. 


\section{Zinc-Binding Transcription Factors}

Transcription factors belong to different protein families. Belonging to the most abundant types of transcription factors are the zinc-binding proteins [14], which form one of the largest families of transcription factors in eukaryotes. These zinc-binding proteins contain amino acid sequences, so called zinc signatures or zinc finger motifs, in which cysteines and/or histidines coordinate one or more zinc atoms to form local peptide structures that are required for their specific functions. These proteins are present in all living beings, from prokaryotes (e.g., Agrobacterium tumefaciens Ros protein) to higher eukaryotes $[15,16]$. The zinc-binding proteins are usually classified into three major classes, and differences in the structure of proteins of the three classes are important in the recognition of their target sequences in the DNA [17]:

Class I contains a signature formed by four amino acids: $\mathrm{Cys}_{2} \mathrm{His}_{2}$ (abbreviated $\mathrm{C}_{2} \mathrm{H}_{2}$ ). This type is the most frequent in higher eukaryotes and is also present in yeast and fungi [18].

The second class contains a signature of $\mathrm{Cys}_{4}$ (abbreviated $\mathrm{C}_{4}$ ), which is more frequent in filamentous fungi.

The third type, which is very important in filamentous fungi, contains a signature sequence of $\mathrm{Cys}_{6}$ and coordinates two zinc atoms per monomer, thus forming the so-called zinc-binding nucleus $\mathrm{Zn}(\mathrm{II})_{2} \mathrm{Cys}_{6}$ (abbreviated $\mathrm{Zn}_{2} \mathrm{C}_{6}$ ). This third class of zinc-binding proteins is exclusive for yeast and filamentous fungi and includes many of the most relevant transcription factors in these organisms. This class is usually referred to as binuclear zinc finger (or simply nuclear zinc finger) transcription factors.

Although the $\mathrm{C}_{2} \mathrm{H}_{2}$ type is the most frequent and was the first discovered in Xenopus at the end of the last century, in recent years many binuclear zinc finger type transcription factors have been found not only in S. cerevisiae and Schizosaccharomyces pombe, but also in many different filamentous fungi (see Tables 1 and 2).

Table 1. Representative examples of class I zinc-binding transcription factors $\left(\mathrm{C}_{2} \mathrm{H}_{2}\right)$ that have been characterized in filamentous fungi.

\begin{tabular}{|c|c|c|c|}
\hline Fungal Species & $\begin{array}{l}\text { Transcription } \\
\text { Factor }\end{array}$ & Process/Function & Reference \\
\hline \multicolumn{4}{|l|}{ Ascomycetes } \\
\hline Acremonium chrysogenum & Cre1 & Glucose catabolite regulation & {$[19,20]$} \\
\hline Aspergillus nidulans & PacC & $\mathrm{pH}$ regulation & [21] \\
\hline Aspergillus nidulans & AslA & $\begin{array}{l}\text { Control of the } \mathrm{K}(+) \text { stress-inducible expression of the genes } \\
\text { encoding the ion pumps }\end{array}$ & [22] \\
\hline Aspergillus nidulans & SltA & Control of morphogenesis and sterigmatocystin biosynthesis & [23] \\
\hline Aspergillus nidulans & $\mathrm{FlbC}$ & $\begin{array}{l}\text { Control of conidial development and germination, and } b r l A \\
\text { and vos } A \text { expression }\end{array}$ & [24] \\
\hline Aspergillus nidulans & NsdC & Control of fruiting body formation & [25] \\
\hline Aspergillus nidulans & MtfA & Regulation of secondary metabolism and differentiation & [26] \\
\hline Aspergillus nidulans & BrlA & Regulation of differentiation & [27] \\
\hline $\begin{array}{l}\text { Aspergillus nidulans, } \\
\text { Penicillium chrysogenum }\end{array}$ & CreA & Glucose catabolite regulation & {$[28,29]$} \\
\hline Aspergillus glaucus & Agseb1 & $\begin{array}{l}\text { Control of sensitivity to hyperosmotic stress. Hyphae } \\
\text { branching and aspergiolide A biosynthesis }\end{array}$ & [30] \\
\hline Botrytis cinerea & $\mathrm{BcYOH} 1$ & $\begin{array}{l}\text { Control of botrydial, phytotoxin and other secondary } \\
\text { metabolites gene clusters }\end{array}$ & [31] \\
\hline Colletotrichum gloeosporioides & CrzA & Control of morphogenetic processes and pathogenicity & [32] \\
\hline Fusarium verticillioides & Ada1 & Control of asexual development & [33] \\
\hline Fusarium verticillioides & Sda1 & Control of polyol metabolism and fumonisin biosynthesis & [34] \\
\hline Magnaporthe oryzae & Znf1 & Control of pathogenicity & [35] \\
\hline
\end{tabular}


Table 1. Cont.

\begin{tabular}{|c|c|c|c|}
\hline Fungal Species & $\begin{array}{l}\text { Transcription } \\
\text { Factor }\end{array}$ & Process/Function & Reference \\
\hline Magnaporthe oryzae & Flb3p & Required for normal aerial mycelium formation & [36] \\
\hline Magnaporthe oryzae & Cos1 & Control of conidiophores development & [37] \\
\hline Saccharomyces cerevisiae & MIG1 & Glucose catabolite regulation & [38] \\
\hline Trichoderma atroviride & Blu7 & Control of light-regulated genes, growth and conidiation & [39] \\
\hline Verticillium dahliae & Czf & $\begin{array}{l}\text { Control of fungal growth, development, various stress } \\
\text { responses, and virulence }\end{array}$ & [40] \\
\hline \multicolumn{4}{|l|}{ Basidiomycetes } \\
\hline Agaricus bisporus & $\mathrm{C}_{2} \mathrm{H}_{2}$ & Control of timing for mushroom formation & [41] \\
\hline Cryptococcus neoformans & Ste12 $\alpha \mathrm{p}$ & Regulation of several genes associated with virulence & [42] \\
\hline Ganoderma lucidum & GlPacC & Control of response to ambient $\mathrm{pH}$ & [43] \\
\hline Schizophyllum commune & $\mathrm{C}_{2} \mathrm{H}_{2}$ & Regulation of primordium development & [44] \\
\hline Ustilago maydis & Mzr1 & Transcriptional activator during host colonization & [45] \\
\hline Ustilago maydis & Rua1 & Regulation of biosurfactant ustilagic acid biosynthesis & [46] \\
\hline
\end{tabular}

Table 2. Representative examples of class III zinc binding transcription factors $\left(\mathrm{Zn}_{2} \mathrm{C}_{6}\right)$ that have been characterized in filamentous fungi.

\begin{tabular}{|c|c|c|c|}
\hline Fungal Species & $\begin{array}{l}\text { Transcription } \\
\text { Factor }\end{array}$ & Process/Function & Reference \\
\hline \multicolumn{4}{|l|}{ Ascomycetes } \\
\hline Aspergillus nidulans & AclR & Activation of genes for ethanol oxidation & {$[47,48]$} \\
\hline Aspergillus nidulans & ArcA & Arginine catabolic pathway & [49] \\
\hline Aspergillus nidulans & NirA & Activation of nitrate assimilation & {$[50,51]$} \\
\hline Aspergillus nidulans & $\operatorname{Prn} A$ & Activation of proline utilization & {$[52,53]$} \\
\hline Aspergillus nidulans & QutA & Regulation of genes for quinic acid utilization & [54] \\
\hline Aspergillus nidulans & QutH & $\begin{array}{l}\text { Possible role in the regulation of protocatechuic acid } \\
\text { utilization }\end{array}$ & [55] \\
\hline Aspergillus nidulans & TamA & Nitrogen regulation & [56] \\
\hline Aspergillus nidulans & Uay & Activation of purine transport and utilization & {$[57,58]$} \\
\hline $\begin{array}{l}\text { Aspergillus nidulans, Aspergillus } \\
\text { oryzae, Aspergillus niger }\end{array}$ & AmyR & Activation of amylolytic gene expression & {$[59,60]$} \\
\hline $\begin{array}{c}\text { Aspergillus nidulans, Neurospora } \\
\text { crassa }\end{array}$ & FacB & Activation of acetate regulatory genes & {$[61,62]$} \\
\hline $\begin{array}{l}\text { Aspergillus oryzae, Aspergillus } \\
\text { niger, Fusarium oxysporum }\end{array}$ & $X \ln R$ & Regulation of xylanolytic genes expression & [63] \\
\hline Aspergillus fumigatus & GliZ & Regulation of gliotoxin & [64] \\
\hline Bipolaris oryzae & Bmr1 & Regulation of melanin biosynthesis & [65] \\
\hline Clonostachys rogersoniana & VerZ & Regulation of verticillin biosynthesis & [66] \\
\hline Colletotricum lindemuthianum & CltA1 & Involved in the regulation of biotrophy/nectotrophy switch & [67] \\
\hline Colletotricum lagenarium & CmR1 & Regulation of melanin biosynthesis & [68] \\
\hline Cercospora nicotianae & CRG1 & Involved in cercosporin resistance & [69] \\
\hline Fusarium verticillioides & Zrf1 & Regulation of fumonisin biosynthesis and sugars transport & [70] \\
\hline Fusarium oxysporum & Fow2 & Control of pathogenicity & [71] \\
\hline $\begin{array}{l}\text { Fusarium graminearum and } \\
\text { F. verticillioides }\end{array}$ & FgArt1 & Regulation of tricotecenos and fumonisin. & [72] \\
\hline Fusarium graminearum & Ebr1 & Involved in growth and virulence & [73] \\
\hline Leptosphaeria maculans & SirZ & Regulation of sirodesmin biosynthesis & [74] \\
\hline
\end{tabular}


Table 2. Cont.

\begin{tabular}{cccc}
\hline Fungal Species & $\begin{array}{c}\text { Transcription } \\
\text { Factor }\end{array}$ & Process/Function & Reference \\
\hline Magnaporthe grisea & Pig1 & Regulation of melanin biosynthesis & {$[68]$} \\
\hline Nectria haematococca & Ctf1 a and b & Activation of cutinases & {$[75]$} \\
\hline Neurospora crassa & Fl & Required for conidiophore morphogenesis & {$[76]$} \\
\hline Neurospora crassa & Nit4 & Activaion of nitrate assimilation & {$[77]$} \\
\hline Penicillium citrinum & MlcR & Involved in compactin biosynthesis & {$[78]$} \\
\hline Penicillium roqueforti & Pcz1 & Regulation of cell development & {$[79]$} \\
\hline Parastagonospora nodorum & PnPf2 & Involved in host specific virulence & {$[80]$} \\
\hline Saccharomyces cerevisiae & ArgRII & Control of arginine metabolism & {$[81]$} \\
\hline Talaromyces marneffei & FacB & Regulation of the glyoxalate cycle & {$[82]$} \\
\hline Trichoderma reesei & AceII & Activation of cellulases and xylanases gene expression & {$[83]$} \\
\hline Sordaria macrospora & Pro1 & Involved in the development of fruiting bodies & {$[84]$} \\
\hline Basidiomycetes & & & {$[85]$} \\
\hline Schizophyllum commune & Fst3 & Regulation of mushroom development & [85] \\
\hline Schizophyllum commune & Fst4 & Regulation of mushroom formation & [86]
\end{tabular}

\subsection{Class I Zinc Binding Transcription Factors $\left(\mathrm{C}_{2} \mathrm{H}_{2}\right)$}

The classical $\mathrm{C}_{2} \mathrm{H}_{2}$ domain contains conserved cysteine and histidine pairs and adopts a left-handed $\beta \beta \alpha$ structure composed of a $\beta$-hairpin (antiparallel $\beta$-sheet comprising two $\beta$-strands) and one $\alpha$-helix, with the amino acid sequence X2-Cys-X2,4-Cys-X12-His-X3,4,5-His (Figure 2). This structure is stabilized by the coordination of a zinc atom with two conserved cysteine residues at one end of the $\beta$ sheet and with two conserved histidine residues at the $\alpha$-helix C-terminus [87]. This structure is frequently repeated in the protein and the protein containing several of these sequences binds as a monomer to its DNA target sequence.

Important examples of the $\mathrm{C}_{2} \mathrm{H}_{2}$ type are the PacC transcriptional regulators of $A$. nidulans and P. chrysogenum, which contain three zinc fingers per monomer [21], the MtfA repressor of A. nidulans [26] or the CreA factor that controls carbon catabolite regulation in many filamentous fungi $[28,88]$. In recent years a large number of fungal transcription factors of class I have been reported (Table 1).

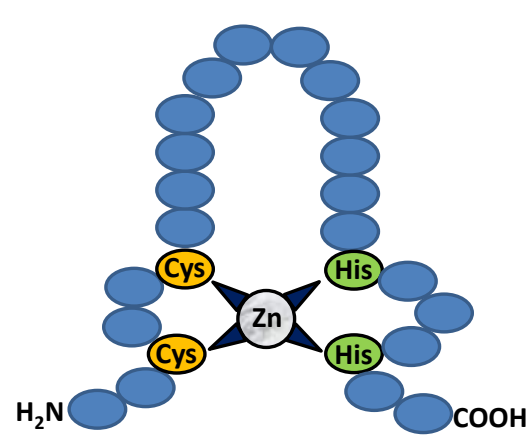

A

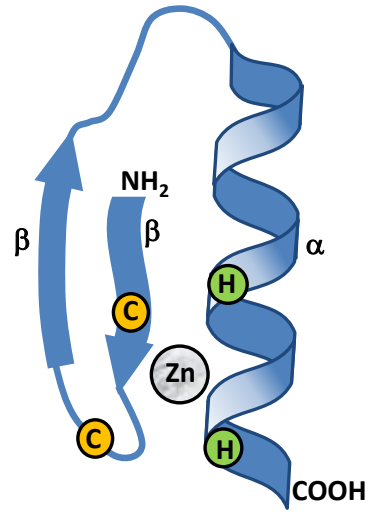

B

Figure 2. Primary (A) and secondary (B) structures of the $\mathrm{C}_{2} \mathrm{H}_{2}$ domain. 


\subsubsection{Class I: CreA (Cre1)}

Media composition has a strong influence in the expression of secondary metabolite gene clusters. Microorganisms have developed a survival strategy based on the selection of the most energetically favorable carbon source, which favors rapid colonization of habitats [89]. The mechanism of carbon source regulation (or carbon catabolite repression), allows preferential assimilation of an energy-efficient and readily utilizable carbon source over a wide variety of relatively less easily accessible carbon sources [90]. In this scenario, glucose and other readily utilized carbon sources are able to repress the expression of different genes, such as those encoding enzymes required for the breakdown of alternative carbon sources (e.g., xylanases, cellulases, and arabinases).

In filamentous fungi, carbon catabolite repression of primary metabolism is mediated by a Cys2-His2-type zinc finger transcription factor named CreA (Cre1) [91], which is an orthologous of MIG1, the final effector responsible for repression of glucose-regulated genes in S. cerevisiae [38]. CreA contains two zinc fingers, an alanine-rich region and frequent S(T)PXX motifs [28], and binds the consensus sequence SYGGRG [92-94]. CreA is regulated to some extent by ubiquitination, the latter promoted by the CreD-HulA ubiquitination ligase complex, whereas the CreB-CreC deubiquitination (DUB) complex removes ubiquitin from CreA, thus causing its activation [91].

Carbon catabolite repression is not exclusively circumscribed to primary metabolism. Biosynthesis of many secondary metabolites is also subject to carbon source regulation. $\beta$-lactam producing fungi represent a good example of how this process controls secondary metabolism.

In P. chrysogenum, glucose, sucrose and to a lesser extent maltose, fructose, and galactose all have a negative effect on penicillin biosynthesis. Interestingly, the use of lactose may overcome this negative effect in the presence of subrepressing doses of glucose [95]. Carbon regulation is exerted at different levels of the penicillin biosynthesis: flux of L- $\alpha$-aminoadipic acid (penicillin precursor); uptake and activation of side chain precursors; transcriptional and post-transcriptional regulation of the penicillin biosynthetic gene cluster [96]. In fact, it has been reported that glucose gives rise to drastic reduction in the transcript levels of the three genes involved in the biosynthesis of penicillin $(p c b A B, p c b C$, and penDE) $[97,98]$ and therefore, a carbon regulatory protein is expected to transduce nutritional signals to the penicillin biosynthetic gene cluster. The important role played by CreA in the control of penicillin biosynthesis has been recently confirmed. Six CreA binding sites (SYGGRG) are present in the intergenic $p c b A B-p c b C$ region of $P$. chrysogenum (Figure 1 ), CreA- 1 being the main cis-acting element regulating carbon repression of the $p c b A B$ gene [99]. In addition, seven putative CreA binding sites have been identified in the promoter region of the penDE gene (Figure 1), although their role in regulating the expression of this penicillin biosynthetic gene has yet to be elucidated.

A similar repression phenomenon has been also observed in $A$. nidulans and $A$. chrysogenum, where glucose or sucrose reduce $\beta$-lactam antibiotic biosynthesis [29,100,101]. In $A$. nidulans, repressing carbon sources regulate ipn $A(p c b C)$ gene expression, at least in part, at the transcriptional level [29], the product of this gene (IPN synthase) showing reduced activity in the presence of glucose. This carbohydrate led to a very weak repressor effect on the $a c v A(p c b A B)$ gene expression [101]. Interestingly, the repression effect on the aat (penDE)-encoding IAT was achieved, at least in part, at post-transcriptional level. This phenomenon was also observed in the wild type strain of P. chrysogenum [101], and was in contrast to previous observations in the improved strain P. chrysogenum AS-P-78 [102], which suggests partial modifications of the glucose-mediated regulation in this penicillin high-producing strain.

Unlike in P. chrysogenum, CreA seems not to play a role in C-source repression of $\beta$-lactam biosynthesis in A. nidulans, since different mutants in CreA, CreB, or CreC did not modify carbon regulation of penicillin biosynthesis $[29,103,104]$. These results indicate that a CreA-independent mechanism of carbon repression controls penicillin biosynthesis in A. nidulans.

In the cephalosporin C-producer $A$. chrysogenum, the repression effect of glucose is more remarkable on cephalosporin $C$ than on penicillin. Therefore, this negative effect seems to be stronger in the late steps of the pathway [100]. The glucose effect on ACV synthetase is exerted 
at post-transcriptional level, since inhibition of ACVS specific activity is due to depletion of the cofactor ATP via sugar metabolism [105]. Conversely, expression of the $p c b C$ and $c e f E F$ genes is controlled by carbon repression in a wild-type strain of $A$. chrysogenum. However, in a cephalosporin C high producing strain, the $p c b C$ transcript level is not affected by the presence of glucose. This suggests that strain improvement is correlated with deregulation of glucose repression $[19,20]$. Control of cephalosporin $\mathrm{C}$ biosynthesis by $\mathrm{Cre1}(\mathrm{CreA})$ has been suggested, and in fact, several binding sites are present in the upstream regions of the biosynthesis genes $p c b C$ and $c e f E F[19,20]$.

\subsubsection{Class I: PacC}

Filamentous fungi can adapt to grow in a wide range of ambient $\mathrm{pH}$ values, thus keeping homeostasis in both acidic and alkaline environments. Regulation of $\mathrm{pH}$-dependent gene expression is these microorganisms is mediated by the transcriptional activator PacC [106], which is a transcription factor of the $\mathrm{Cys}_{2} \mathrm{His}_{2}$-type with three zinc fingers [107].

Under acidic conditions, the full-length form of PacC (PacC72) adopts a close conformation that is inaccessible to the activating proteases. This is due to intramolecular interactions involving the $\mathrm{C}$-terminal domain [108]. On the contrary, at neutral to alkaline $\mathrm{pH}$, activation of $\mathrm{PacC}$ is initiated in response to a signaling cascade involving dedicated Pal signal transduction components (A, B, C, F, H, and I) and the participation of ESCRT-I, -II, and -III components (endosomal sorting complex required for transport) $[109,110]$.

The plasma membrane signaling complex includes three components: (i) the cell surface sensor $\mathrm{PalH}$, which contains seven transmembrane domains and senses the extracellular $\mathrm{pH}$ level [111,112]; (ii) PalI, which assists plasma membrane localization of PalH [113]; and (iii) PalF, an arrestin-related protein that stabilizes PalH through strong interactions and is phosphorylated and ubiquitinated under neutral to alkaline conditions $[114,115]$. This results in endocytosis of the PalH/PalF complex to endomembranes, recruitment of ESCRT components, and incorporation of PalC, PalA, and PalB [116].

This cascade leads to the activation of PacC by a two-step proteolytic cleavage. During the first step, which occurs in response to $\mathrm{pH}$ signaling, PalA interacts with the two YPXL/I motifs flanking the cleavage site in PacC72 [117], whereas the cysteine protease PalB removes approximately $180{ }^{\circ} \mathrm{C}$-terminal residues to yield PacC53 [118-120]. In the second step, which is pH-independent and most likely mediated by the proteasome, PacC53 is converted to PacC27 [121]. Under neutral to alkaline conditions, the PacC27 processed form prevents transcription of those genes expressed preferentially at acidic $\mathrm{pH}$ and activates transcription of alkaline expressed genes [21,106].

Steady-state levels of pacC transcripts are low under acidic $\mathrm{pH}$ values and relatively high under alkaline conditions in wild-type strains [106]. It has been reported that the unprocessed PacC72 negatively autoregulates $\mathrm{pacC}$ gene expression, the latter occurring under alkaline conditions due to derepression after PacC72 processing in response to $\mathrm{pH}$ signaling [110].

Biosynthesis of each fungal secondary metabolite is optimal at a certain $\mathrm{pH}$ condition. Interestingly, production of $\beta$-lactam antibiotics by P. chrysogenum (hydrophobic penicillins) and A. chrysogenum (cephalosporin $\mathrm{C}$ ) is favored under alkaline ambience $\mathrm{pH}$ values [122,123]. Under these conditions, PacC activates gene expression by binding the consensus sequence 5'-GCCARG-3' [106]. The promoter region of the genes involved in the biosynthesis of penicillin and cephalosporin $C$ contains several PacC binding sites. In P. chrysogenum, the three genes involved in the biosynthesis of penicillin seem to be regulated by $\mathrm{PacC}$, since seven putative binding sites are present in the $p c b A B-p c b C$ intergenic region and three putative binding sites are found within the promoter region of the pen $D E$ gene [122] (Figure 1). In A. chrysogenum, putative PacC binding sites have been found in the promoter region of "early" and "late" genes involved in the biosynthesis of cephalosporin C. In this microorganism the bi-directional promoters of the genes $p c b A B-p c b C$ and $c e f E F-c e f G$ contain two PacC binding sites each [123]. These data suggest PacC-mediated $\mathrm{pH}$ regulation of full penicillin biosynthesis process and partial $\mathrm{pH}$ regulation of cephalosporin $\mathrm{C}$ biosynthesis. In addition, $\mathrm{PacC}$-dependent regulation of cephalosporin $\mathrm{C}$ biosynthesis seems to have changed during strain improvement, since the optimum 
$\mathrm{pH}$ value for the expression of the genes involved in the biosynthesis of cephalosporin in a wild-type strain was $\mathrm{pH} 8$, unlike in a production strain, where the optimum $\mathrm{pH}$ value was $\mathrm{pH} 6$ [123].

Regulation of $\beta$-lactam biosynthetic gene expression by $\mathrm{pH}$ is related to another important environmental factor that dramatically affects the biosynthesis of $\beta$-lactam antibiotics; the carbon source. The use of repressing carbon sources (e.g., glucose or sucrose) causes acidification of the culture medium, whereas non-repressing carbon sources (e.g., lactose) produce alkalinization. Therefore, although carbon source and $\mathrm{pH}$ have independent regulatory mechanisms, both carbon and $\mathrm{pH}$ regulation act in concert [106,124]. In A. nidulans the alkaline external $\mathrm{pH}$ is able to override the negative effect of a repressing carbon source on the ipnA $(p c b C)$ gene expression, unlike in P. chrysogenum, where full $p c b C$ gene expression was dependent on carbon source derepression irrespective of the ambient $\mathrm{pH}[97,122]$.

\subsubsection{Class I: MTFA (Master Transcription Factor A)}

A novel zinc binding transcription factor was reported in A. nidulans [26]. This transcription factor regulates several secondary metabolite biosynthesis independently of the VeA regulatory protein. The same secondary metabolites are also controlled by VeA through interaction with LaeA and several other proteins of the velvet complex. Ramamoorthy and coworkers [26] searched for transcription factors controlling secondary metabolism and sexual and asexual reproduction in A. nidulans in a VeA-defective strain. The new transcription factor, named Master Transcription Factor A (MTFA), belongs to the $\mathrm{C}_{2} \mathrm{H}_{2}$ class and its monomeric protein contains two zinc binding domains per molecule. MTFA controls sterigmatocystin, penicillin, and terrequinone biosynthesis in A. nidulans. The biosynthesis of penicillin decreases in mutants deleted in the MTFA transcription factor and, interestingly, overexpression of $m t f A$ leads to a five-fold increase in penicillin biosynthesis due to modulation of the expression of the three penicillin biosynthesis genes $p c b A B, p c b C$, and $p e n D E$. Remarkably, the biosynthesis of sterigmatocystin and terrequinone does not follow the same pattern. Although production of these other secondary metabolites decreases in the MTFA mutant, there is no increase in the production of these metabolites when the MTFA gene is overexpressed in the wild type parental strain. This inhibitory effect suggests that in the case of sterigmatocystin and terrequinone, there is a critical level of MTFA that is optimal for the biosynthesis of these secondary metabolites. The MTFA factor regulates at least two genes of the terrequinone biosynthesis; $t d i A$ and $t d i B$. The $t d i A$ gene encodes an indol prenyltransferase that catalyzes the first step of terrequinone biosynthesis. Deletion of the MTFA gene and complementation with the wild type allele changes the expression of the AflR regulatory gene of the sterigmatocystin gene cluster, hence indicating that a critical level of MTFA is optimal for sterigmatocystin biosynthesis. Fluorescence electron microscope studies using MTFA-GFP fused proteins indicated that the MTFA factor is located in the nucleus, both under dark and light conditions, and regulates sexual and asexual sporulation. This regulation is connected to changes in expression of the VeA transcription factor. In the MTFA deletion mutant, expression of blrA is abnormally high, a condition that correlates with repression of conidiation [125]. MTFA homologous genes have been found in a number of Ascomycetes fungi, but not in yeasts, plants, or animals. In particular, the MTFA orthologous gene of P. chrysogenum is encoded by Pc22g24110 (Accession number XP_002566301.1). P. chrysogenum and A. nidulans MTFA genes share $49.3 \%$ identity and $58.7 \%$ similarity, and it is likely that the MTFA gene of $P$. chrysogenum might also control the expression of the $p c b A B, p c b C$, and $p e n D E$ genes.

\subsection{Class II Zinc Binding Transcription Factors $\left(C_{4}\right)$}

The $\mathrm{C}_{4}$ class includes well known transcription factors, such as the nuclear receptor proteins and the so called GATA factors [126]. The majority of the fungal GATA factors contain a single zinc finger domain with the amino acid sequence Cys-X2-Cys-X17,18-Cys-X2-Cys followed by a highly basic region [127] (Figure 3). This class of transcription factors binds to GATA sequences ((A/T)GATA(A/G)) present in target promoters. The protein usually binds as homodimers or heterodimers to the recognition sequence [128]. Homodimers bind inverted GATA repeat sequences, whereas heterodimers recognize direct repeated sequences. Interesting examples of class II transcription factors are AreA of 
A. nidulans (named NreI in P. chrysogenum or AcareA in A. chrysogenum), which controls the nitrogen regulation in these fungi attaching to GATA sequences [129-131], and Sre1, the latter controlling iron uptake and siderophore biosynthesis in Histoplasma capsulatum [132].

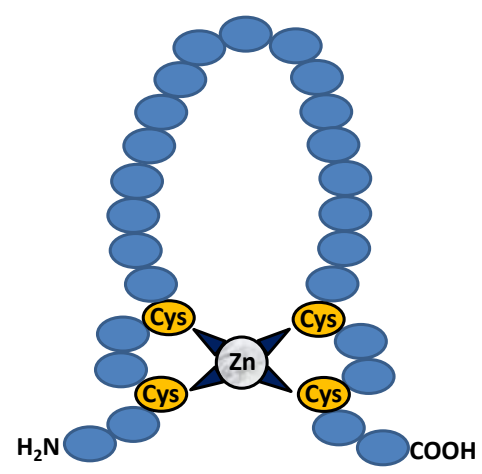

A

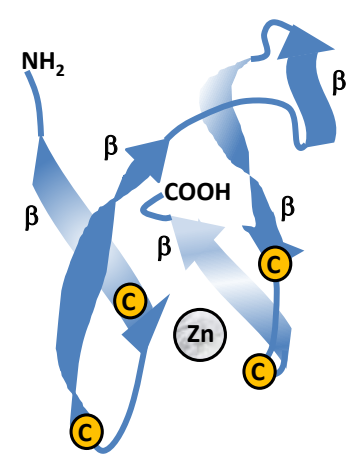

B

Figure 3. Primary (A) and secondary (B) structures of the $C_{4}$ domain.

\section{Class II: AreA (Nre)}

A constant nitrogen supply is necessary to assure fungal growth under different environmental conditions. This supply is achieved by means of a wide-domain regulatory system known as nitrogen metabolite repression. When preferred nitrogen sources, such as ammonium or glutamine, are absent, alternative nitrogen sources (e.g., amino acids, GABA, purines, etc.) can be used. This process is controlled by this system, which regulates components of the nitrate assimilation machinery and also permeases and catabolic enzymes [96,129,133,134].

In ascomycetous fungi, the key player in charge of activating (de-repression mechanism) those genes involved in the utilization of alternative nitrogen sources in the absence of preferred ones, is the transcription factor AreA (dubbed Nre in P. chrysogenum) [121]. AreA/NRE contain a single Cys-X2-Cys-X17-Cys-X2-Cys (Cys2Cys2) zinc finger domain preferentially binding to at least two HGATAR (GATA) DNA sequence motifs within a range of 30 bp [96,129,135].

During nitrogen starvation, nitrate assimilation in $A$. nidulans is controlled by AreA. This GATA transcription factor is able to open the chromatin at the nitrate utilization gene cluster via histone acetylation and act synergistically with the nitrate-induced transcription factor NirA, which ultimately binds the target promoter region of the nitrate assimilatory genes for transcription initiation [136-138].

An additional GATA transcription factor (AreB in A. nidulans or NreB in P. chrysogenum) has been also reported to be involved in nitrogen regulation in these two filamentous fungi. AreB (NreB) was initially considered the negative counterpart of AreA (Nre), thus playing a role as a major repressor of AreA-activated nitrogen catabolism genes [139,140]. Recent studies have reported more complex functions for AreB, which acts synergistically with AreA as activators or repressors of their shared target genes and physically interacts in the nucleus under nitrogen-limiting conditions [141]. In addition, they are involved in the control of several complex cellular processes like carbon metabolism and transport, and can be considered as master regulators of secondary metabolism [142].

$\beta$-lactam antibiotic production by P. chrysogenum and A. chrysogenum is strongly influenced by the nitrogen source. An ammonium concentration above $100 \mathrm{mM}$ strongly interfered with cephalosporin C production in A. chrysogenum [143], whereas the addition of $40 \mathrm{mM}$ ammonium to $P$. chrysogenum grown in the presence of lactose led to the repression of expression of the reporter uidA gene from both $p c b A B$ and $p c b C$ promoters, thus indicating that the expression of each of these penicillin biosynthesis genes is regulated by nitrogen repression [144]. In fact, the bidirectional promoter region $p c b A B-p c b C$ of P. chrysogenum contains five GATA motifs (Figure 1). Only NRE strongly interacts in vitro with a site that contains two of these GATA motifs, which are arranged in a head-to-head fashion and separated 
by $27 \mathrm{bp}$ [145]. Therefore, nitrogen metabolite regulation of the genes involved in the biosynthesis of penicillin mediated by Nre seems very likely, pointing to these secondary metabolism genes as members of a nitrogen control circuit [96]. The A. chrysogenum intergenic region of the corresponding $p c b A B-p c b C$ genes also contains several GATA motifs (up to 15), thus suggesting AreA-mediated nitrogen repression of cephalosporin production [146]. In fact, it has been reported that AreA binds to the bidirectional promoter of $p c b A B-p c b C$ in this microorganism, thus playing an important role not only in the regulation of nitrogen metabolism, but also in cephalosporin production [131]. Interestingly, in $A$. nidulans the bidirectional $a c v A-i p n A(p c b A B-p c b C)$ promoter region only contains one GATA motif, which is consistent with the fact that no evidence for nitrogen-dependent regulation of penicillin biosynthesis has been reported so far in this filamentous fungus [96].

\subsection{Class III Zinc Binding Transcription Factors $\left(\mathrm{Zn}_{2} \mathrm{C}_{6}\right)$}

Zinc-binding transcription factors of class III contain two sets of three cysteines, flanked by basic amino acids, each one coordinating a zinc atom and thus forming the so-called zinc finger. Therefore, the two zinc atoms are coordinated by six cysteine molecules. These binuclear transcription factors contain a DNA binding domain that is usually located in the amino terminal region of the protein (exceptionally in the carboxyl terminal end) and has the amino acid sequence Cys-X2-CysX6-Cys-X5-12-Cys-X2-Cys-X6-9-Cys (Figure 4). These proteins may work as monomers, homodimers, or heterodimers. The DNA-binding domain is tripartite and consists of the signal sequence $\mathrm{Cys}_{6}$, a linker region, and the dimerization region. The signal sequence is made of two groups of three cysteine molecules separated by a loop [147].

The classical model protein of class III is the Gal4p protein, which is a regulatory protein for galactose utilization in yeast (Figure 5) [148]. A few of these zinc-binding proteins have been crystallized, including Gal4p [149,150], their crystal structures providing information on how they form homodimers [151]. The crystal structure reveals that these type of transcription factors bind to two repeated CGG sequences separated by a different number of nucleotides. The zinc atom is required for binding the transcription factor to the DNA, but it can be replaced by cadmium [152,153]. Indeed, some of the crystal structures were obtained with cadmium instead of zinc. While the recognized motif consists of two direct repeat CGG sequences, some of these transcription factors bind to inverted CGG sequences separated by a variable linker. The variable linker region may explain the different specificity of the recognized regions by distinct zinc binding proteins; this variable region somehow provides a rigid distance that determines the specificity of recognition of the different binding sequences [154].

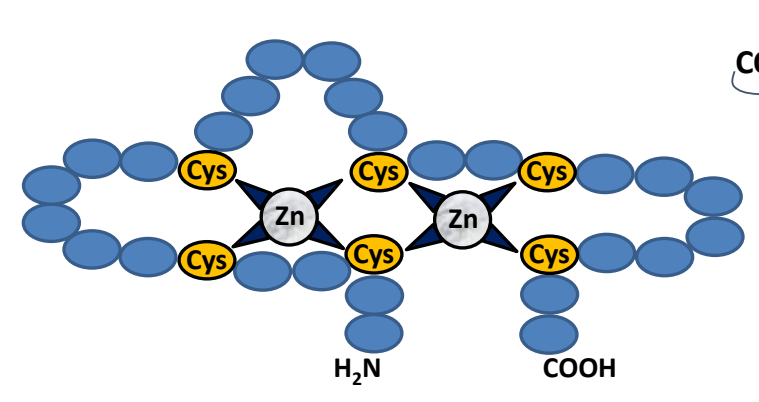

A

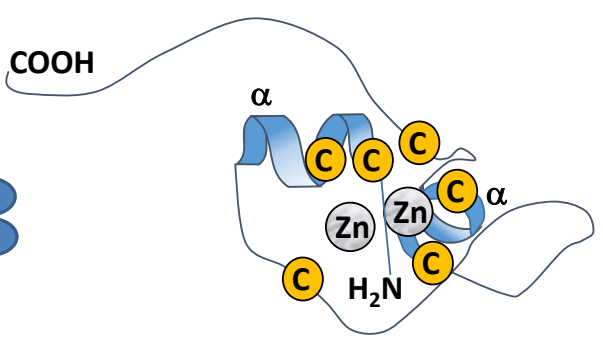

B

Figure 4. Primary (A) and secondary (B) structures of the $\mathrm{Zn}_{2} \mathrm{C}_{6}$ domain. 


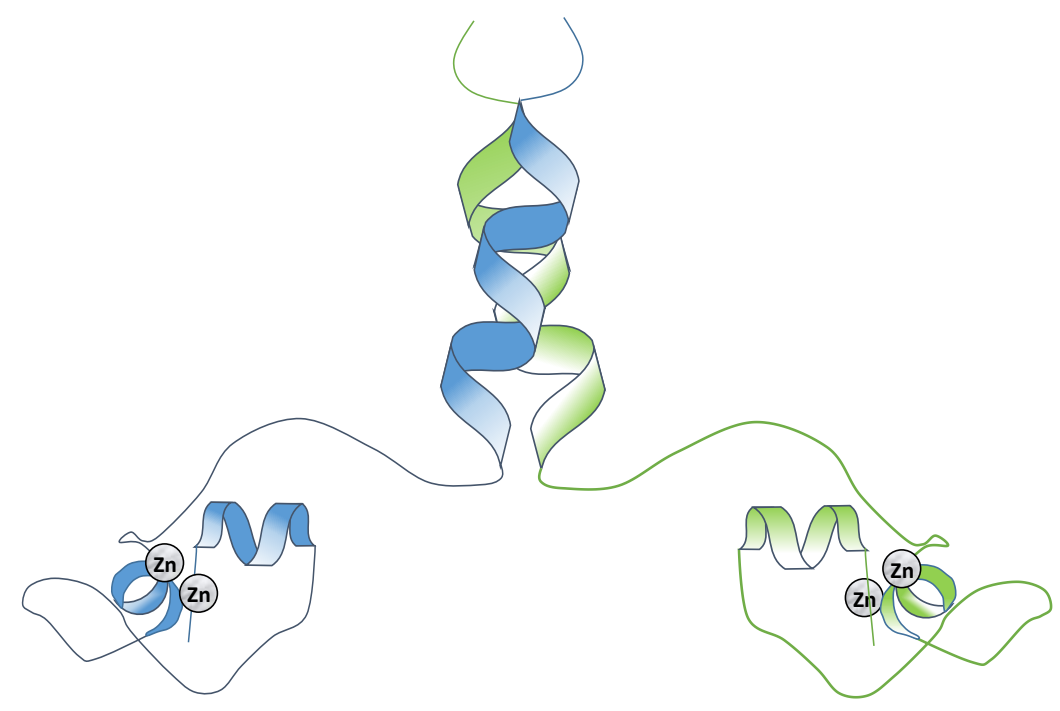

Figure 5. Dimeric structure of the Gal4p $\mathrm{Zn}_{2} \mathrm{C}_{6}$ transcription factor.

The third element of the tripartite DNA binding domain is the dimerization domain. This domain consists of heptad repeats that form coil structures, and the dimerization appears to take place by coil to coil interaction in a form similar to that of the leucine zipper. Most zinc-binding transcription factors contain this dimerization coil region, but a few of them lack the dimerization capability, indicating that the latter work as monomers. The middle homology region is poorly conserved among different members of these zinc finger factors. This region has a regulatory role and appears to be important in the modulation of the transcriptional activity of those factors. Indeed, mutants in these regions are sometimes constitutive, which indicates that the middle homology region plays a role in regulation of the transcriptional activity, most likely an inhibitory role. Finally, the C-terminal region of these transcription factors is usually acidic and probably plays different functions in distinct transcription factors. Some of them have transmembrane domains, thus suggesting that this region may serve to anchor the protein to membrane systems, whereas in other cases it has a modulatory role of the transcription factor activity [17].

Specificity and Binding of the Binuclear Zinc Finger Transcription Factors

Despite the overall structure similarity between hundreds of these factors, they have notable recognition specificity. There are several features that determine binding specificity. One of them is the orientation of the CGG triplets in the binding site; in some cases, there are direct repetitions of the CGG, whereas in others inverted repeats are present. Moreover, the distance between the CGG triplets introduces another variable in the specificity. In general, binding of transcription factor dimers to these sequences takes place by two proteins bound either in a face to face configuration (in the case of recognition of inverted CGG repeats), or in face to tail configuration (in the case of direct CGG repeat) [17].

However, comparison of the recognition sites of a certain transcription factor reveals a considerable variability, thus indicating that other features different from the nucleotide sequence are also important [155]. Indeed, chip studies with chromatin immunoprecipitation indicate that some transcription factors bind to many nucleotide sequences in the intergenic regions of the $S$. cerevisiae genome, some of which do not contain the consensus target sequence [156].

There are hundreds of binuclear transcription factors in yeasts and filamentous fungi. About fifty of these proteins have been described in S. cerevisiae and Candida albicans [17], but in recent years many more examples of zinc finger transcription factors have been found in different filamentous fungi. These transcription factors play very important roles in the regulation of fungal differentiation, sporulation, secondary metabolite biosynthesis, and primary metabolism (Table 2). 


\section{Winged Helix Regulators}

Winged helix regulators are a large and diverse set of evolutionarily conserved transcription factors formed by members of the RFX and the forkhead families [157]. These transcription factors are found in all organisms, from bacteria to mammals, but their functional properties and interaction profile are diverse and versatile.

Winged helix proteins share an evolutionarily conserved DNA-binding domain and belong to the ensemble of helix-turn-helix proteins. The winged helix motif is a compact $\alpha / \beta$ structure consisting of two wings, three $\alpha$ helices, and three $\beta$ strands [158] (Figure 6).

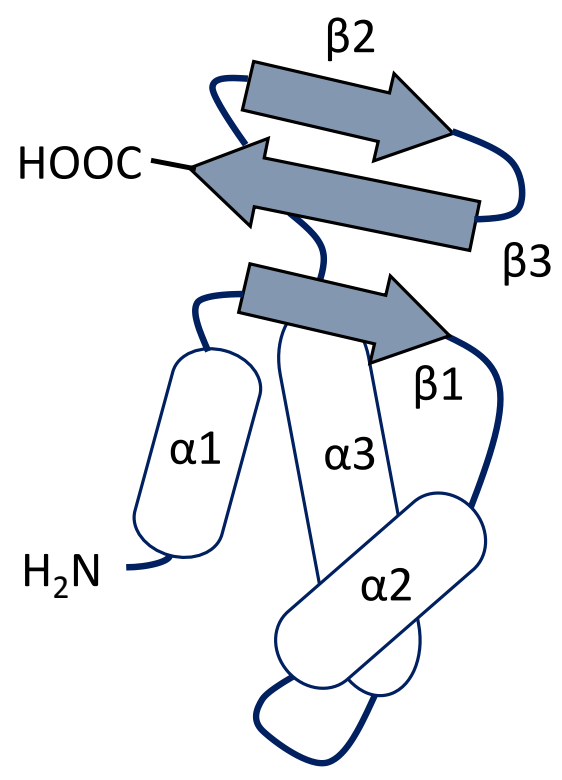

Figure 6. Topology of the winged helix domain.

\subsection{RFX-Related Transcription Regulators}

RFX transcripcional factors form a small class of winged helix proteins and are characterized by a nonconventional mode of DNA recognition.

In A. chrysogenum, CPCR1 is the first member of the RFX transcription factors identified from filamentous fungi. It is involved in the regulation of cephalosporin $C$ biosynthesis. This transcription factor only binds DNA in a dimeric state and is involved in the regulation of cephalosporin $C$ biosynthesis by binding, at least, two sequences at the bidirectional promoter region of the $p c b A B-p c b C$ genes of $A$. chrysogenum [159]. Knockout transformants in $c p c R 1$ showed decreased transcript levels of the $p c b C$ gene, as well as a reduction in the penicillin $\mathrm{N}$ production, but not in cephalosporin $\mathrm{C}$ levels. Therefore, CPCR1 is not likely involved in the regulation of the late genes of the cephalosporin biosynthetic cluster $[159,160]$.

CPCR1 homologous proteins have been found in $\beta$-lactam non-producer fungi, such as Neurospora crassa and Fusarium graminearum, thus indicating that this factor may have different regulatory functions not restricted to antibiotic biosynthesis. In fact, it has been shown that CPCR1 is also involved in the control of morphological development and is necessary for hyphal fragmentation, and hence for the formation of arthrospores in A. chrysogenum [161]. Also, in the opportunistic human pathogenic fungus, Penicillium marneffei, RfxA (CPCR1 ortholog) may be required for linking cell division with cellular differentiation during morphogenesis, mainly in the process of conidiation and growth under yeast form [162].

In P. chrysogenum, the global transcription factor PcRFX1 (orthologous of the A. chrysogenum CPCR1) controls penicillin biosynthesis. Domínguez-Santos and coworkers [163] established a new consensus sequence for the binding of PcRFX1 to the penicillin biosynthetic gene promoters 
( $5^{\prime}$-NNRCCNNRSHWAY-3'). Using this consensus sequence, two putative binding sites in the promoter region of $p c b A B$, one in the promoter region of $p c b C$ and another one in the promoter region of $p e n D E$, were found (Figure 1). The functionality of these putative PcRFX1 DNA binding sequences was verified using gene reporter assays. Furthermore, by means of DNA binding assays, specific interaction of PcRFX1 with the putative DNA binding sequences located in the penicillin biosynthetic gene promoters was demonstrated. Pcrfx1 knockdown transformants showed a reduction in isopenicillin $\mathrm{N}$ and penicillin $\mathrm{G}$ production, which was a consequence of a decreased expression of the penicillin gene cluster. Therefore, PcRFX1 controls the early and late steps of the penicillin biosynthetic process in P. chrysogenum. In this filamentous fungus, PcRFX1 is also suggested to control several pathways of primary metabolism [163].

\subsection{Forkhead-Type Regulators}

In a similar way to CPCR1 (RFX), forkhead transcription factors also form a subclass of winged helix transcription factors [158]. Consensus binding sites have been determined for this type of regulators, including seven core nucleotides $5^{\prime}-\mathrm{G} / \mathrm{AT} / \mathrm{CC} / \mathrm{AAAT} / \mathrm{CA}-3^{\prime}$ from 17 different sequences [164].

The first member of the forkhead family to be characterized in filamentous fungi was AcFKH1. This transcription factor is associated with the RFX transcription factor CPCR1 in $A$. chrysogenum $[161,165]$. AcFKH1 has two conserved domains; the N-terminal forkhead-associated domain (FHA), which could be involved in phospho-protein interactions, and the C-terminal DNA-binding domain (FKH) of the winged helix/forkhead type. This transcription factor controls cephalosporin $C$ biosynthesis through the recognition of two consensus binding sequences inside the $p c b A B-p c b C$ promoter region of $A$. chrysogenum. Although this factor is not directly involved in the fragmentation of hyphae, its interaction seems to be necessary for the functionality of CPCR1 in the morphogenesis of this fungus [161]. These authors suggested that CPCR1, together with AcFKH1, represents a molecular link between secondary metabolism (antibiotic production) and morphogenesis (arthrospore formation). Therefore, these two transcription factors are of utmost importance in the control of fungal growth during cephalosporin production.

In P. chrysogenum, PcFKH1 (orthologous of AcFKH1) has been reported to control antibiotic production. The promoter regions of the genes involved in the biosynthesis of penicillin were analyzed in search for putative FKH1 binding sites using the consensus sequences $5^{\prime}$-RYMAAYA-3' [166], which is a modification of the binding sequence reported by Kaufmann and coworkers [164]. PcFKH1-binding sites were not found "in silico" in the promoter region of the $p c b A B$ gene, whereas two binding sites were identified within the $p c b C$ and $p e n D E$ gene promoters (Figure 1). Expression analyses carried out in Pcfkh1 knockdown transformants and DNA binding assays showed that PcFKH1 positively controls the expression of the penDE gene through specific interaction with the promoter region of this gene, thus confirming the involvement of this transcription factor in the control of penicillin biosynthesis. In addition, PcFKH1 also controls the expression of ancillary genes of the penicillin biosynthesis, such as phlA and ppt, which encode a phenylacetyl-CoA ligase and a phosphopantetheinyl transferase, respectively. These two important genes are involved in the synthesis of penicillin precursors and activation of the $\alpha$-aminoadipyl-cysteinyl-valine synthetase (encoded by the $p c b A B$ gene). Furthermore, this factor also acts on conidiation and spore pigmentation in the improved laboratory reference strain P. chrysogenum Wisconsin 54-1255, although it is not involved in hyphal morphology [166]. A genome-wide analysis of processes putatively coregulated by PcFKH1 and PcRFX1 was made in P. chrysogenum. This analysis suggested that these two factors are likely involved in the control of several primary metabolism pathways as well [166].

\section{Global Regulators of Secondary Metabolism}

Several global regulators play important roles in balancing growth, sporulation, and secondary metabolite production in filamentous fungi. 


\subsection{The LaeA Transcription Factor and Heterochromatin Reorganization}

LaeA (loss of aflR expression-A), a global secondary metabolite regulator, controls the synthesis of several secondary metabolites including carcinogens (sterigmatocystin), antibiotics (penicillin), antihypercholesterolemic agents (lovastatin), mycotoxins (aflatoxin, gliotoxin), anthraquinones (endocrocin), and bioactive metabolites (pseurotin) [167-172]. LaeA, described for the first time in Aspergillus species, is a nuclear methyltransferase that contains a methyltransferase domain with several S-adenosylmethionine (SAM) binding sites and a predicted nuclear localization signal near the $\mathrm{N}$ terminus (Figure 7), which is correlated with the putative role of this protein in chromatin remodeling [172]. Amino acid comparison among LaeA proteins of A. nidulans, A. fumigatus, N. crassa, Magnaporthe grisea, Coccidioides immitis, and Fusarium sporotrichioides shows exactly the same SAM binding sites that are found in histone methyltransferases and arginine methyltransferases. However, LaeA lacks other conserved domains (e.g., a SET domain, a double E loop) typically detected in this methyltransferase protein family [173]. A. nidulans laeA gene has three putative AflR binding sites, one in the promoter region and two in the encoding region, and one intron [168]. Deletion of lae $A$ blocks the expression of sterigmatocystin, penicillin, and lovastatin biosynthetic gene clusters in $A$. nidulans. Expression of ipnA (encoding isopenicillin $\mathrm{N}$ synthase) was considerably reduced in the $\Delta l a e A$ strain. On the contrary, overexpression of laeA leads to increased penicillin and lovastatin production. The spore production in $\triangle l a e A$ strains was similar to that of the wild type, evidencing that the role of LaeA is primarily played in the regulation of secondary metabolite gene clusters [168].

In P. chrysogenum, the laeA gene (PclaeA) was first isolated and characterized by Kosalková and coworkers [174] as a homologous gene of the $A$. nidulans and $A$. fumigatus laeA genes. PcLaeA shows $61 \%$ and $60 \%$ amino acid identity to the orthologous protein of $A$. nidulans and $A$. fumigatus, respectively. The deduced PcLaeA sequence possesses the conserved SAM binding site of protein methyltransferases, which is found in the LaeA protein of other filamentous fungi. The PclaeA gene is present as a single copy in the genome of low- and high-penicillin producing strains, and is located outside of the $56.8 \mathrm{~kb}$ region that is amplified in high-penicillin producing strains. This fact indicates that the chromosomal region including PclaeA has not been reorganized during the process of strain improvement.

Overexpression of PclaeA resulted in an increase in the transcript level of $p c b C$ and penDE genes. This led to increased benzylpenicillin production as compared to the parental strain. PclaeA knockdown mutants showed reduced levels of penicillin biosynthetic gene expression and antibiotic production. In these mutants, the expression of $p c b C$ and $p e n D E$ genes was downregulated (the $p c b C$ gene expression showed larger reduction), which is concordant with the hypothesis of LaeA having a preferential effect on chromatin organization in divergent promoter regions. Conversely, the steady state levels of the gene transcripts involved in the roquefortine alkaloid biosynthesis ( $\mathrm{dmaW}$ gene) were similar to those observed in the wild-type parental strain. This fact is probably related to the chromatin arrangement in the low-expression roquefortine promoters. In addition, the knockdown PclaeA mutant exhibited a reduced level in the production of at least one hydrophilic compound. Nevertheless, the production of different metabolites was increased in the loss-of-function mutant. A similar phenomenon has also been found in $A$. nidulans, where the biosynthesis of different secondary metabolites is regulated either positively or negatively by LaeA [175]. These data indicate the complex regulatory network controlling the secondary metabolism in filamentous fungi [174].

Interestingly, PclaeA knockdown transformants showed pigmentation and sporulation defects [174], and a P. chrysogenum strain carrying a deletion of the PclaeA gene failed in conidiophore development in both light and dark conditions [176], thus confirming that PcLaeA not only controls some secondary metabolism gene clusters, but also asexual differentiation.

Even though the exact function of LaeA has not been totally deciphered, there is evidence of the relationship between chromatin modification and LaeA activity. Chromatin remodeling is an important regulatory mechanism in the biosynthesis of fungal secondary metabolites. It seems that secondary metabolism clusters are silenced by heterochromatic histone marks and that "closed" heterochromatic structures are reversed to euchromatin during activation of secondary metabolism through a process 
mediated by LaeA $[177,178]$. However, the exact mechanism of direct or indirect LaeA involvement in the modification of the chromatin structure is not completely known [179]. LaeA also shows S-methylmethionine auto-methylation activity; nevertheless this activity is not essential for function [180].

Although the role of LaeA in the control of secondary metabolism is very well stablished, participation of this transcription factor in the regulation of primary metabolism has not yet been evidenced. For example, it has been reported that the transcription of the lys1 gene that encodes homocitrate synthase (the first enzyme of the lysine pathway), seems not to be regulated by LaeA. The reason for this phenomenon might be that primary metabolism genes do not require the same transcription factors as secondary metabolism genes, the latter strongly interacting with LaeA [172].

Due to capacity of LaeA to act as a global regulator of secondary metabolism, the discovery of new molecules that can regulate its expression is another interesting aspect. For example, it has been reported that 1,3-diaminopropane and spermidine are able to enhance PclaeA transcript levels and increase penicillin titers [181].

\subsection{The Velvet Complex}

Since the discovery of the key regulator of secondary metabolism LaeA in A. nidulans, numerous studies focused on this transcription factor have been conducted in different filamentous fungi. Among the fruits of these investigations was the finding that LaeA interacts with members of the velvet complex, which is involved in coordinating secondary metabolism and differentiation processes. The velvet complex consists of $\mathrm{VeA}$ (VelA), VelB, VelC, and VosA proteins, which are highly conserved among ascomycetes and basidiomycetes [182]. In P. chrysogenum, the velvet domain, a conserved amino acid motif with high sequence similarity to the velvet domain described for $A$. nidulans, is located next to the $\mathrm{N}$ terminus of PcVeA and PcVosA. However, in PcVelC this motif is located in the $\mathrm{C}$ terminus of the protein. In PcVelB, the velvet domain is split into two parts; one placed in the $\mathrm{N}$ terminus and the other one in the $\mathrm{C}$ terminus. A nuclear localization signal was detected in PcVeA, PcVelB, PcVosA, and PcVelC. One additional nuclear localization signal was detected at the $\mathrm{C}$ terminus of PcVelC. In addition, for PcVelC, a predicted nuclear export sequence was detected within the velvet domain at the $C$ terminus [183] (Figure 7).

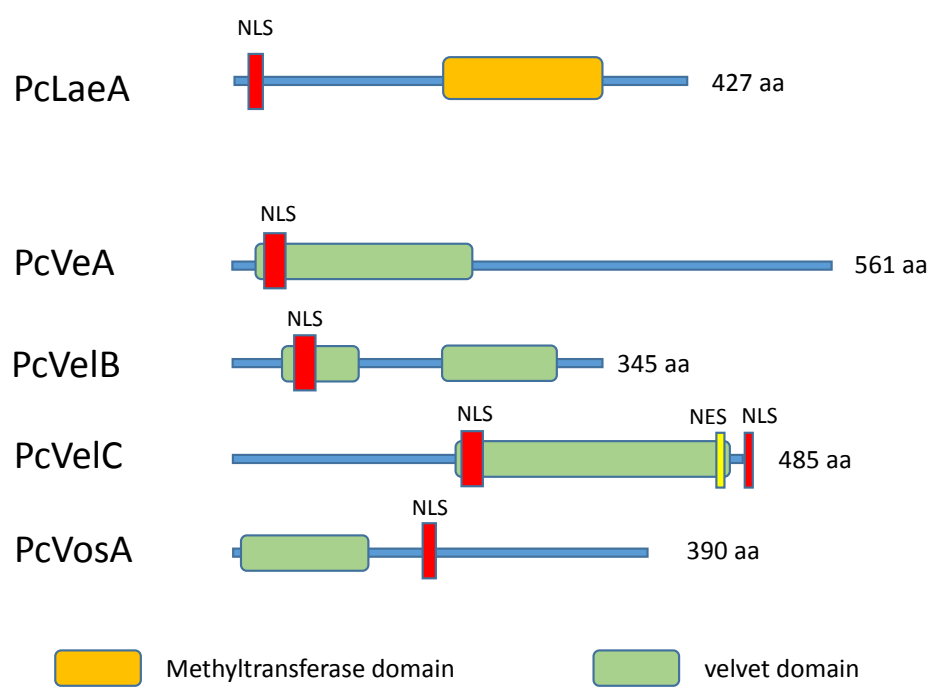

Figure 7. Conserved domains in PcLaeA, PcVeA, PcVelB, PcVelC, and PcVosA. Predicted nuclear localization signals (NLS, red) and putative nuclear export sequences (NES, yellow) are also indicated (adapted from [183]).

Members of the velvet complex interact with each other and with LaeA in the fungal nucleus. Since the discovery of the velvet complex in $A$. nidulans, it has been described in several 
fungi $[176,184-186]$. The role of the velvet complex is critical in understanding the transcription processes in filamentous fungi, and some proteins in the complex participate in processes of the fungal response to light. VeA and VelB in Aspergillus are DNA binding proteins [182], and together with LaeA, constitute the core of the velvet complex in A. nidulans. Under light conditions, LaeA reduces the levels of VelB and VeA and proper asexual development can occur. In darkness, VeA and VelB are necessary for forming fruiting bodies and join LaeA to create a heterotrimeric complex $[168,184]$. In the absence of LaeA, velvet proteins are not suppressed and sexual development is permitted [182]. VosA, also interacts in the dark with VelB, and the heterodimer VosA-VelB downregulates asexual spore formation. A clear role was provided for the three velvet regulators VeA, VelB, and VosA in A. nidulans, unlike the function of VelC, which remained initially unanswered. More recently, it was reported that VelC positively controls sexual development [187].

The LaeA-velvet complex has great significance for increasing the production of new secondary metabolites, especially those whose production is very low due to silent state of genes involved in their biosynthesis [172]. Regarding regulation of $\beta$-lactam antibiotics by this complex, LaeA, $\mathrm{VeA}$, and VelC are positive regulators of the penicillin biosynthesis in a high producing strain of P. chrysogenum, whereas VelB has the opposite effect [183]. In A. chrysogenum, VeA positively controls the expression of all six cephalosporin $C$ biosynthesis genes. In addition, the veA disruption strains showed accelerated formation of arthrospores and hyperbranching of hyphal tips on osmotically nonstabilized media [188]. By means of a comparative gene expression analysis of wild-type and production strains of A. chrysogenum and P. chrysogenum, it was revealed that the expression of target genes of the velvet complex were altered as a consequence of strain improvement programs [189]. These authors concluded that regulatory changes are decisive factors for improved $\beta$-lactam antibiotic production during strain improvement programs in both fungi. In addition, analysis of the lae $A$ and $v e A$ encoding genes in high penicillin producing strains revealed that these transcription factors acquired important mutations during the strain improvement programs, resulting in differential expression of those genes involved in the biosynthesis of secondary metabolites [172].

\section{Concluding Remarks}

As detailed above, there are many transcription factors that affect the expression of genes involved in primary and secondary metabolism in filamentous fungi. A major role is played by zinc-binding proteins of classes I, II, or III. These types of transcription factors include the well-known major transcription factors that control carbon catabolite regulation (CreA), the $\mathrm{pH}$ controlling transcription factor PacC, GATA factors (such as NreI or AreA), and binuclear zinc fingers. Another important group of transcription factors in filamentous fungi include the winged helix factors, such as RFX and forkhead proteins. Additionally, although they are not strictly speaking transcription factors, LaeA and the velvet complex proteins play critical roles in the regulation of metabolism in filamentous fungi, particularly in genes involved in secondary metabolism and morphological differentiation. Although there is important knowledge on these transcription factors and regulatory proteins, many of the details linking them to the transcription of the genes involved in the biosynthesis of secondary metabolites are still poorly known. A final interesting finding is that the promoters of many of the genes involved in the biosynthesis of secondary metabolites, particularly those that are expressed from bidirectional promoter regions, contain multiple binding sites for these transcription factors (Figure 1), which are located next to each other in the operator region and determine the interaction between different transcription factors. Even in some cases, overlapping of the binding sites for certain transcription factors may occur and therefore, the interaction of these regulatory proteins will be a subject of great interest over the next few years.

Author Contributions: All authors contributed to the bibliographic revision process. C.G.-E. and J.-F.M. wrote and formatted the paper.

Funding: This research received no external funding. 
Acknowledgments: Authors wish to thank Paloma Liras for her valuable support and critical revision of this article.

Conflicts of Interest: The authors declare no conflict of interest.

\section{References}

1. Johnston, S.R.; Boddy, L.; Weightman, A.J. Bacteria in decomposing wood and their interactions with wood-decay fungi. FEMS Microbiol. Ecol. 2016, 92. [CrossRef]

2. Janusz, G.; Pawlik, A.; Sulej, J.; Swiderska-Burek, U.; Jarosz-Wilkolazka, A.; Paszczynski, A. Lignin degradation: Microorganisms, enzymes involved, genomes analysis and evolution. FEMS Microbiol. Rev. 2017, 41, 941-962. [CrossRef] [PubMed]

3. Shen, Y.; Liu, N.; Li, C.; Wang, X.; Xu, X.; Chen, W.; Xing, G.; Zheng, W. The early response during the interaction of fungal phytopathogen and host plant. Open Biol. 2017, 7, 170057. [CrossRef] [PubMed]

4. Dickie, I.A.; Bufford, J.L.; Cobb, R.C.; Desprez-Loustau, M.L.; Grelet, G.; Hulme, P.E.; Klironomos, J.; Makiola, A.; Nuñez, M.A.; Pringle, A.; et al. The emerging science of linked plant-fungal invasions. New Phytol. 2017, 215, 1314-1332. [CrossRef] [PubMed]

5. Karathia, H.; Vilaprinyo, E.; Sorribas, A.; Alves, R. Saccharomyces cerevisiae as a model organism: A comparative study. PLoS ONE 2011, 6, e16015. [CrossRef] [PubMed]

6. Adrio, J.L.; Demain, A.L. Fungal Biotechnology. Int. Microbiol. 2003, 6, 191-199. [CrossRef] [PubMed]

7. Demain, A.L. Valuable Secondary Metabolites from fungi. In Biosynthesis and Molecular Genetics of Fungal Secondary Metabolites; Martín, J.F., García-Estrada, C., Zeilinger, S., Eds.; Springer Verlag: New York, NY, USA, 2014; Volume 1, pp. 1-15. ISBN 978-1-4939-1190-5.

8. Zeillinger, S.; García-Estrada, C.; Martin, J.F. Fungal Secondary metabolites in the OMICS Era. In Biosynthesis and Molecular Genetics of Fungal Secondary Metabolites; Zeilinger, S., Martín, J.F., García-Estrada, C., Eds.; Springer Verlag: New York, NY, USA, 2015; Volume 2, pp. 1-12. ISBN 978-1-4939-5516-9.

9. Van den Berg, M.A.; Albang, R.; Albermann, K.; Badger, J.H.; Daran, J.M.; Driessen, A.J.; Garcia-Estrada, C.; Fedorova, N.D.; Harris, D.M.; Heijne, W.H.; et al. Genome sequencing and analysis of the filamentous fungus Penicillium chrysogenum. Nat. Biotechnol. 2008, 26, 1161-1168. [CrossRef] [PubMed]

10. Calvo, A.M.; Wilson, R.A.; Bok, J.W.; Keller, N.P. Relationship between secondary metabolism and fungal development. Microbiol. Mol. Biol. Rev. 2002, 66, 447-459. [CrossRef] [PubMed]

11. Yu, J.H.; Keller, N. Regulation of secondary metabolism in filamentous fungi. Annu. Rev. Phytopathol. 2005, 43, 437-458. [CrossRef] [PubMed]

12. Laich, F.; Fierro, F.; Martín, J.F. Production of penicillin by fungi growing on food products: Identification of a complete penicillin gene cluster in Penicillium griseofulvum and a truncated cluster in Penicillium verrucosum. Appl. Environ. Microbiol. 2002, 68, 1211-1219. [CrossRef] [PubMed]

13. Martín, J.F.; Ullán, R.V.; García-Estrada, C. Regulation and compartmentalization of $\beta$-lactam biosynthesis. Microb. Biotechnol. 2010, 3, 285-299. [CrossRef] [PubMed]

14. Cassandri, M.; Smirnov, A.; Novelli, F.; Pitolli, C.; Agostini, M.; Malewicz, M.; Melino, G.; Raschellà, G. Zinc-finger proteins in health and disease. Cell Death Discov. 2017, 3, 17071. [CrossRef] [PubMed]

15. Seetharam, A.; Stuart, G.W. A study on the distribution of 37 well conserved families of C2H2 zinc finger genes in eukaryotes. BMC Genom. 2013, 14, 420. [CrossRef] [PubMed]

16. Malgieri, G.; Palmieri, M.; Russo, L.; Fattorusso, R.; Pedone, P.V.; Isernia, C. The prokaryotic zinc-finger: Structure, function and comparison with the eukaryotic counterpart. FEBS J. 2015, 282, 4480-4496. [CrossRef] [PubMed]

17. MacPherson, S.; Larochelle, M.; Turcotte, B. A fungal family of transcriptional regulators: The zinc cluster proteins. Microbiol. Mol. Biol. Rev. 2006, 70, 583-604. [CrossRef] [PubMed]

18. Siggers, T.; Reddy, J.; Barron, B.; Bulyk, M.L. Diversification of transcription factor paralogs via noncanonical modularity in $\mathrm{C} 2 \mathrm{H} 2$ zinc finger DNA binding. Mol. Cell 2014, 55, 640-648. [CrossRef] [PubMed]

19. Jekosch, K.; Kück, U. Glucose dependent transcriptional expression of the cre1 gene in Acremonium chrysogenum strains showing different levels of cephalosporin C production. Curr. Genet. 2000, 37, 388-395. [CrossRef] [PubMed] 
20. Jekosch, K.; Kück, U. Loss of glucose repression in an Acremonium chrysogenum beta-lactam producer strain and its restoration by multiple copies of the cre1 gene. Appl. Microbiol. Biotechnol. 2000, 54, 556-563. [CrossRef] [PubMed]

21. Espeso, E.A.; Peñalva, M.A. Three binding sites for the Aspergillus nidulans PacC zinc-finger transcription factor are necessary and sufficient for regulation by ambient $\mathrm{pH}$ of the isopenicillin $\mathrm{N}$ synthase gene promoter. J. Biol. Chem. 1996, 271, 28825-28830. [CrossRef] [PubMed]

22. Park, D.S.; Yu, Y.M.; Kim, Y.J.; Maeng, P.J. Negative regulation of the vacuole-mediated resistance to K(+) stress by a novel $\mathrm{C} 2 \mathrm{H} 2$ zinc finger transcription factor encoded by aslA in Aspergillus nidulans. J. Microbiol. 2015, 53, 100-110. [CrossRef] [PubMed]

23. Shantappa, S.; Dhingra, S.; Hernández-Ortiz, P.; Espeso, E.A.; Calvo, A.M. Role of the zinc finger transcription factor SltA in morphogenesis and sterigmatocystin biosynthesis in the fungus Aspergillus nidulans. PLoS ONE 2013, 8, e68492. [CrossRef] [PubMed]

24. Kwon, N.J.; Garzia, A.; Espeso, E.A.; Ugalde, U.; Yu, J.H. FlbC is a putative nuclear C2H2 transcription factor regulating development in Aspergillus nidulans. Mol. Microbiol. 2010, 77, 1203-1219. [CrossRef] [PubMed]

25. Kim, H.R.; Chae, K.S.; Han, K.H.; Han, D.M. The $n s d C$ gene encoding a putative C2H2-type transcription factor is a key activator of sexual development in Aspergillus nidulans. Genetics 2009, 182, 771-783. [CrossRef] [PubMed]

26. Ramamoorthy, V.; Dhingra, S.; Kincaid, A.; Shantappa, S.; Feng, X.; Calvo, A.M. The putative $\mathrm{C} 2 \mathrm{H} 2$ transcription factor MtfA is a novel regulator of secondary metabolism and morphogenesis in Aspergillus nidulans. PLoS ONE 2013, 8, e74122. [CrossRef] [PubMed]

27. Adams, T.H.; Wieser, J.K.; Yu, J.H. Asexual Sporulation in Aspergillus nidulans. Microbiol. Mol. Biol. Rev. 1998, 62, 35-54. [PubMed]

28. Dowzer, C.E.; Kelly, J.M. Analysis of the creA gene, a regulator of carbon catabolite repression in Aspergillus nidulans. Mol. Cell. Biol. 1991, 11, 5701-5709. [CrossRef] [PubMed]

29. Espeso, E.A.; Peñalva, M.A. Carbon catabolite repression can account for the temporal pattern of expression of a penicillin biosynthetic gene in Aspergillus nidulans. Mol. Microbiol. 1992, 6, 1457-1465. [CrossRef] [PubMed]

30. Wu, Y.; Ren, Y.; Zhou, X.; Cai, M.; Zhang, Y. Transcription factor Agseb1 affects development, osmotic stress response, and secondary metabolism in marine-derived Aspergillus glaucus. J. Basic Microbiol. 2017, 57, 873-882. [CrossRef] [PubMed]

31. Simon, A.; Dalmais, B.; Morgant, G.; Viaud, M. Screening of a Botrytis cinerea one-hybrid library reveals a Cys2His2 transcription factor involved in the regulation of secondary metabolism gene clusters. Fungal Genet. Biol. 2013, 52, 9-19. [CrossRef] [PubMed]

32. Dubey, A.K.; Barad, S.; Luria, N.; Kumar, D.; Espeso, E.A.; Prusky, D.B. Cation-stress-responsive transcription factors SltA and CrzA regulate morphogenetic processes and pathogenicity of Colletotrichum gloeosporioides. PLoS ONE 2016, 11, e0168561. [CrossRef] [PubMed]

33. Malapi-Wight, M.; Kim, J.E.; Shim, W.B. The N-terminus region of the putative $\mathrm{C} 2 \mathrm{H} 2$ transcription factor Ada1 harbors a species-specific activation motif that regulates asexual reproduction in Fusarium verticillioides. Fungal Genet. Biol. 2014, 62, 25-33. [CrossRef] [PubMed]

34. Malapi-Wight, M.; Smith, J.; Campbell, J.; Bluhm, B.H.; Shim, W.B. Sda1, a Cys2-His2 zinc finger transcription factor, is involved in polyol metabolism and fumonisin B1 production in Fusarium verticillioides. PLoS ONE 2013, 8, e67656. [CrossRef] [PubMed]

35. Yue, X.; Que, Y.; Xu, L.; Deng, S.; Peng, Y.; Talbot, N.J.; Wang, Z. ZNF1 encodes a putative C2H2 Zinc-finger protein essential for appressorium differentiation by the rice blast fungus Magnaporthe oryzae. Mol. Plant Microbe Interact. 2016, 29, 22-35. [CrossRef] [PubMed]

36. Matheis, S.; Yemelin, A.; Scheps, D.; Andresen, K.; Jacob, S.; Thines, E.; Foster, A.J. Functions of the Magnaporthe oryzae Flb3p and Flb4p transcription factors in the regulation of conidiation. Microbiol. Res. 2017, 196, 106-117. [CrossRef] [PubMed]

37. Li, X.; Han, X.; Liu, Z.; He, C. The function and properties of the transcriptional regulator COS1 in Magnaporthe oryzae. Fungal Biol. 2013, 117, 239-249. [CrossRef] [PubMed]

38. Nehlin, J.O.; Ronne, H. Yeast MIG1 repressor is related to the mammalian early growth response and Wilms' tumour finger proteins. EMBO J. 1990, 15, 2891-2898. 
39. Cetz-Chel, J.E.; Balcázar-López, E.; Esquivel-Naranjo, E.U.; Herrera-Estrella, A. The Trichoderma atroviride putative transcription factor Blu7 controls light responsiveness and tolerance. BMC Genom. 2016, $17,327$. [CrossRef] [PubMed]

40. Xiong, D.; Wang, Y.; Deng, C.; Hu, R.; Tian, C. Phylogenic analysis revealed an expanded $\mathrm{C}_{2} \mathrm{H}_{2}$-homeobox subfamily and expression profiles of $\mathrm{C}_{2} \mathrm{H}_{2}$ zinc finger gene family in Verticillium dahliae. Gene 2015, 562, 169-179. [CrossRef] [PubMed]

41. Pelkmans, J.F.; Vos, A.M.; Scholtmeijer, K.; Hendrix, E.; Baars, J.J.; Gehrmann, T.; Reinders, M.J.; Lugones, L.G.; Wösten, H.A. The transcriptional regulator c2h2 accelerates mushroom formation in Agaricus bisporus. Appl. Microbiol. Biotechnol. 2016, 100, 7151-7159. [CrossRef] [PubMed]

42. Chang, Y.C.; Wright, L.C.; Tscharke, R.L.; Sorrell, T.C.; Wilson, C.F.; Kwon-Chung, K.J. Regulatory roles for the homeodomain and $\mathrm{C} 2 \mathrm{H} 2$ zinc finger regions of Cryptococcus neoformans Ste12alphap. Mol. Microbiol. 2004, 53, 1385-1396. [CrossRef] [PubMed]

43. Wu, F.L.; Zhang, G.; Ren, A.; Dang, Z.H.; Shi, L.; Jiang, A.L.; Zhao, M.W. The pH-responsive transcription factor PacC regulates mycelial growth, fruiting body development, and ganoderic acid biosynthesis in Ganoderma lucidum. Mycologia 2016, 108, 1104-1113. [CrossRef] [PubMed]

44. Ohm, R.A.; de Jong, J.F.; de Bekker, C.; Wösten, H.A.B.; Lugones, L.G. Transcription factor genes of Schizophyllum commune involved in regulation of mushroom formation. Mol. Microbiol. 2011, 15, 1433-1445. [CrossRef] [PubMed]

45. Zheng, Y.; Kief, J.; Auffarth, K.; Farfsing, J.W.; Mahlert, M.; Nieto, F.; Basse, C.W. The Ustilago maydis Cys2His2-type zinc finger transcription factor Mzr1 regulates fungal gene expression during the biotrophic growth stage. Mol. Microbiol. 2008, 68, 1450-1470. [CrossRef] [PubMed]

46. Teichmann, B.; Liu, L.; Schink, K.O.; Bölker, M. Activation of the ustilagic acid biosynthesis gene cluster in Ustilago maydis by the $\mathrm{C} 2 \mathrm{H} 2$ zinc finger transcription factor Rua1. Appl. Environ. Microbiol. 2010, 76, 2633-2640. [CrossRef] [PubMed]

47. Kulmburg, P.; Judewicz, N.; Mathieu, N.; Lenouvel, F.; Sequeval, D.; Felenbok, B. Specific binding sites for the activator protein ALcR in the alcA promoter of the ethanol regulon in Aspergillus nidulans. J. Biol. Chem. 1992, 267, 21146-21153. [PubMed]

48. Nikolaev, I.; Lenouvel, F; Felenbok, B. Unique DNA binding specificity of the binuclear zinc AlcR activator of the ethanol utilization pathway in Aspergillus nidulans. J. Biol. Chem. 1999, 274, 9795-9802. [CrossRef] [PubMed]

49. Empel, J.; Sitkiewicz, I.; Andrukiewicz, A.; Lasocki, K.; Borsuk, P.; Weglenski, P. arcC, the regulatory gene for the arginine catabolic pathway in Aspergillus nidulans. Mol. Gen. Genom. 2001, 266, 591-597. [CrossRef] [PubMed]

50. Burger, G.; Strauss, J.; Scazzocchio, C.; Lang, B.F. nirA, the pathway-specific regulatory gene of nitrate assimilation in Aspergillus nidulans, encodes a putative Gal4-type zinc finger protein and contains four introns in highly conserved regions. Mol. Cell. Biol. 1991, 11, 5746-5755. [CrossRef] [PubMed]

51. Punt, P.J.; Strauss, J.; Smit, R.; Kinghorn, J.R.; van den Hondel, C.A.; Scazzocchio, C. The intergenic region between the divergently transcribed niaA and niaD genes of Aspergillus nidulans contains multiple NirA binding sites which act bidirectionally. Mol. Cell. Biol. 1995, 15, 5688-5699. [CrossRef] [PubMed]

52. Cazell, B.; Pokorska, A.; Hull, E.; Green, P.M.; Stanway, G.; Scazzocchio, C. Sequence, exon-intron organization transcription and mutational analysis of $p r n A$, the gene encoding the transcriptional activator of the prn gene cluster in Aspergillus nidulans. Mol. Microbiol. 1998, 28, 355-370. [CrossRef]

53. Gómez, D.; Cubero, B.; Cecchetto, G.; Scazzocchio, C. PrnA, a Zn(2)Cys(6) activator with a unique DNA recognition mode, requires inducer for in vivo binding. Mol. Microbiol. 2002, 44, 585-598. [CrossRef] [PubMed]

54. Levesley, I.; Newton, G.H.; Lamb, H.K.; Vanschothorst, E.; Dalgleish, R.W.M.; Samson, A.C.R.; Roberts, C.F.; Hawkins, A.R. Domain-structure and function within the QUTA protein of Aspergillus nidulans-implications for the control of transcription. Microbiology 1996, 142, 87-98. [CrossRef] [PubMed]

55. Lamb, H.K.; Roberts, C.F.; Hawkins, A.R. A second gene (qutH) within the Aspergillus nidulans quinic acid utilization gene cluster encodes a protein with a putative zinc-cluster motif. Gene 1992, 112, $219-224$. [CrossRef] 
56. Davis, M.A.; Small, A.J.; Kourambas, S.; Hynes, M.J. The tamA gene of Aspergillus nidulans contains a putative zinc cluster motif which is not required for gene function. J. Bacteriol. 1996, 178, 3406-3409. [CrossRef] [PubMed]

57. Ceccetto, G.; Amillis, S.; Diallinas, G.; Scazzochio, C.; Drevet, C. The AzgA purine transporter of Aspergillus nidulans. Characterization of a protein belonging to a new phylogenetic cluster. J. Biol. Chem. 2004, 279, 3132-3141. [CrossRef] [PubMed]

58. Suárez, T.; Queiroz, M.V.; Oestreicher, N.; Scazzocchio, C. The sequence and binding specificity of UaY, the specific regulator of the purine utilization pathway in Aspergillus nidulans suggest an evolutionary relationship with the PPR1 of Saccharomyces cerevisiae. EMBO J. 1995, 14, 1453-1467. [PubMed]

59. Gomi, K.; Akeno, T.; Minetoki, T.; Ozeki, K.; Kumagai, C.; Okazaki, N.; Iimura, Y. Molecular cloning and characterization of a transcriptional activator gene, amyR, involved in the amylolytic gene expression in Aspergillus oryzae. Biosci. Biotechnol. Biochem. 2000, 64, 816-827. [CrossRef] [PubMed]

60. Tani, S.; Katsuyama, Y.; Hayashi, T.; Suzuki, H.; Kato, M.; Gomi, K.; Kobayashi, T.; Tsukagoshi, N. Characterization of the $a m y R$ gene encoding a transcriptional activator for the amylase genes in Aspergillus nidulans. Curr. Genet. 2001, 39, 10-15. [CrossRef] [PubMed]

61. Todd, R.B.; Nurphy, R.L.; Martin, H.M.; Sharps, J.A.; Davis, M.A.; Katz, M.E.; Hynes, M.J. The acetate regulatory gene FacB of Aspergillus nidulans encodes a $\mathrm{Zn}(\mathrm{II}) 2 \mathrm{Cys} 6$ transcriptional activator. Mol. Gen. Genet. 1997, 254, 495-504. [CrossRef] [PubMed]

62. Todd, R.B.; Andrianopoulos, A.; Davis, M.A.; Hynes, M.J. FacB, the Aspergillus nidulans activator of acetate utilization genes, binds dissimilar DNA sequences. EMBO J. 1998, 17, 2042-2054. [CrossRef] [PubMed]

63. Hasper, A.A.; Visser, J.; Graaff, L.H. The Aspergillus niger transcriptional activator XlnR, which is involved in the degradation of the polysaccharides xylan and cellulose, also regulates D-xylose reductase gene expression. Mol. Microbiol. 2000, 36, 193-200. [CrossRef] [PubMed]

64. Gardiner, D.M.; Howlett, B.J. Bioinformatic and expression analysis of the putative gliotoxin biosynthetic gene cluster of Aspergillus fumigatus. FEMS Microbiol. Lett. 2005, 248, 241-248. [CrossRef] [PubMed]

65. Kihara, J.; Moriwaki, A.; Tanaka, N.; Tanaka, C.; Ueno, M.; Arase, S. Characterization of the BMR1 gene encoding a transcription factor for melanin biosynthesis genes in the phytopathogenic fungus Bipolaris oryzae. FEMS Microbiol. Lett. 2008, 281, 221-227. [CrossRef] [PubMed]

66. Guo, Z.; Hao, T.; Wang, Y.; Pan, Y.; Ren, F.; Liu, X.; Che, Y.; Liu, G. VerZ, a Zn(II)2Cys6 DNA-binding protein, regulates the biosynthesis of verticillin in Clonostachys rogersoniana. Microbiology 2017, 163, 1654-1663. [CrossRef] [PubMed]

67. Dufresne, M.; Perfect, S.; Pellier, A.L.; Bailey, J.A.; Langin, I. A Gal4-like protein is involved in the switch between biotrophic and necrotrophic phases of the infection process of Colletotrichum lindemuthianum on common vean. Plant Cell. 2000, 12, 1579-1589. [CrossRef] [PubMed]

68. Tsuji, G.; Kenmochi, Y.; Takano, J.; Sweigard, J.; Farrall, L.; Furusawa, I.; Horino, O.; Kubo, Y. Novel fungal transcriptional activator, Cmr1p of Colletotrichum lagenarium and Pig1p of Magnaporthe grisea, contain Cys2His2 zinc finger and $\mathrm{Zn}(\mathrm{II}) 2 \mathrm{Cys} 6$ binuclear cluster DNA-binding motifs and regulate transcription of melanin biosynthesis genes in a developmental manner. Mol. Microbiol. 2000, 38, 940-954. [PubMed]

69. Chung, K.R.; Daub, M.E.; Kuchler, K.; Schuller, C. The CRG1 gene required for resistance to the singlet oxygen-generating cercosporin toxin in Cercospora nicotianae encodes a putative fungal transcription factor. Biochem. Biophys. Res. Commun. 2003, 302, 302-310. [CrossRef]

70. Flaherty, J.E.; Woloshuk, C.P. Regulation of the fumonisin biosynthesis in Fusarium verticilloides by a zinc binuclear cluster-type gene, ZFR1. Appl. Environ. Microbiol. 2004, 70, 2653-2659. [CrossRef] [PubMed]

71. Imazaki, I.; Kurahashi, M.; Iida, Y.; Tsuge, T. Fow2, a Zn(II)2Cys6-type transcription regulator, controls plant infection of the vascular wilt fungus Fusarium oxysporum. Mol. Microbiol. 2007, 63, 737-753. [CrossRef] [PubMed]

72. Oh, M.; Son, H.; Choi, G.J.; Lee, C.; Kim, J.C.; Kim, H.; Lee, Y.W. Transcription factor ART1 mediates starch hydrolysis and mycotoxin production in Fusarium graminearum and F. verticillioides. Mol. Plant Pathol. 2016, 17, 755-768. [CrossRef] [PubMed]

73. Zhao, C.; Waalwijk, C.; de Wit, P.J.; van der Lee, T.; Tang, D. EBR1, a novel Zn(2)Cys(6) transcription factor, affects virulence and apical dominance of the hyphal tip in Fusarium graminearum. Mol. Plant. Microbe Interact. 2011, 24, 1407-1418. [CrossRef] [PubMed] 
74. Fox, E.M.; Gardiner, D.M.; Keller, N.P.; Howlett, B.J. A Zn(II)2Cys6 DNA binding protein regulates the sirodesmin PL biosynthetic gene cluster in Leptosphaeria maculans. Fungal Genet. Biol. 2008, 45, 671-682. [CrossRef] [PubMed]

75. Li, D.X.; Kolattukudy, P.E. Cloning of cutinase transcription factor 1, a transactivating protein containing Cys(6)Zn(2) binuclear cluster DNA_binding motif. J. Biol. Chem. 1997, 272, 12462-12467. [CrossRef] [PubMed]

76. Bailey, L.A.; Ebbole, D.J. The Fluffy gene of Neurospora crassa encodes a Gal4p-type C6 zinc cluster protein required for conidial development. Genetics 1998, 148, 1813-1820. [PubMed]

77. Feng, B.; Marzluf, G.A. The regulatory protein NIT4 that mediates nitrate induction in Neurospora crassa contains a complex tripartite activation domain with a novel leucine-rich, acidic motif. Curr. Genet. 1996, 29, 537-548. [CrossRef] [PubMed]

78. Abe, Y.; Ono, C.; Hosobuchi, M.; Yoshikawa, H. Functional analysis of $m l c R$, a regulatory gene for ML-236B (compactin) biosynthesis in Penicillium citrinum. Mol. Genet. Genom. 2002, 268, 352-361. [CrossRef] [PubMed]

79. Gil-Duran, C.; Rojas-Aedo, J.F.; Medina, E.; Vaca, I.; García-Rico, R.O.; Villagrán, S.; Levicán, G.; Chávez, R. The pcz1 gene, which encodes a $\mathrm{Zn}(\mathrm{II}) 2 \mathrm{Cys} 6$ protein, is involved in the control of growth, conidiation, and conicidial germination in the filamentous fungus Penicillium roqueforti. PLoS ONE 2015, 10, e0120740. [CrossRef] [PubMed]

80. Rybak, K.; See, P.T.; Phan, H.T.; Syme, R.A.; Moffat, C.S.; Oliver, R.P.; Tan, K.C. A functionally conserved $\mathrm{Zn}(2) \mathrm{Cys}(6)$ binuclear cluster transcription factor class regulates necrotrophic effector gene expression and host-specific virulence of two major Pleosporales fungal pathogens of wheat. Mol. Plant. Pathol. 2017, 18, 420-434. [CrossRef] [PubMed]

81. Messenguy, F.; Dubois, E.; Descamps, F. Nucleotide sequence of the ARGRII regulatory gene and amino acid sequence homologies between ARGRII PPRI and GAL4 regulatory proteins. Eur. J. Biochem. 1986, 15, 77-81. [CrossRef]

82. Canovas, D.; Andrianopoulus, A. Developmental regulation of the glyoxalate cycle in the human pathogen Penicillium marneffei. Mol. Microbiol. 2006, 62, 1725-1738. [CrossRef] [PubMed]

83. Aro, N.; Saloheimo, A.; Ilmen, M.; Pentilla, M. ACEII, a novel transcriptional activator involved in regulation of cellulase and xylanase genes in Trichoderma reesei. J. Biol. Chem. 2001, 276, 24309-24314. [CrossRef] [PubMed]

84. Masloff, S.; Poggeler, S.; Kuck, U. The pro1+ gene from Sordaria macrospora encodes a C6 zinc finger transcription factor required for fruiting body development. Genetics 1999, 152, 191-199. [PubMed]

85. Ohm, R.A.; de Jong, J.F.; Lugones, L.G.; Aerts, A.; Kothe, E.; Stajich, J.E.; de Vries, R.P.; Record, E.; Levasseur, A.; Baker, S.E.; et al. Genome sequence of the model mushroom Schizophyllum commune. Nat. Biotechnol. 2010, 15, 957-963. [CrossRef] [PubMed]

86. Horst, R.J.; Zeh, C.; Saur, A.; Sonnewald, S.; Sonnewald, U.; Voll, L.M. The Ustilago maydis Nit2 homolog regulates nitrogen utilization and is required for efficient induction of filamentous growth. Eukaryot Cell. 2012, 11, 368-380. [CrossRef] [PubMed]

87. Fedotova, A.A.; Bonchuk, A.N.; Mogila, V.A.; Georgiev, P.G. C2H2 Zinc finger proteins: The largest but poorly explored family of higher eukaryotic transcription factors. Acta Naturae 2017, 9, 47-58. [PubMed]

88. Esperón, P.; Scazzocchio, C.; Paulino, M. In vitro and in silico analysis of the Aspergillus nidulans DNA-CreA repressor interactions. J. Biomol. Struct. Dyn. 2014, 32, 2033-2041. [CrossRef] [PubMed]

89. Ruijter, G.J.; Visser, J. Carbon repression in Aspergilli. FEMS Microbiol. Lett. 1997, 151, 103-114. [CrossRef] [PubMed]

90. Ronne, H. Glucose repression in fungi. Trends Genet. 1995, 11, 12-17. [CrossRef]

91. Adnan, M.; Zheng, W.; Islam, W.; Arif, M.; Abubakar, Y.S.; Wang, Z.; Lu, G. Carbon catabolite repression in filamentous fungi. Int. J. Mol. Sci. 2017, 19, 48. [CrossRef] [PubMed]

92. Cubero, B.; Scazzocchio, C. Two different, adjacent and divergent zinc finger binding sites are necessary for CREA-mediated carbon catabolite repression in the proline gene cluster of Aspergillus nidulans. EMBO J. 1994, 13, 407-415. [PubMed]

93. Cubero, B.; Gómez, D.; Scazzocchio, C. Metabolite repression and inducer exclusion in the proline utilization gene cluster of Aspergillus nidulans. J. Bacteriol. 2000, 182, 233-235. [CrossRef] [PubMed] 
94. Kulmburg, P.; Mathieu, M.; Dowzer, C.; Kelly, J.; Felenbok, B. Specific binding sites in the alcR and alcA promoters of the ethanol regulon for the CREA repressor mediating carbon catabolite repression in Aspergillus nidulans. Mol. Microbiol. 1993, 7, 847-857. [CrossRef] [PubMed]

95. Revilla, G.; López-Nieto, M.J.; Luengo, J.M.; Martín, J.F. Carbon catabolite repression of penicillin biosynthesis by Penicillium chrysogenum. J. Antibiot. Tokyo 1984, 37, 781-789. [CrossRef] [PubMed]

96. Brakhage, A.A. Molecular Regulation of Beta-lactam Biosynthesis in Filamentous Fungi. Microbiol. Mol. Biol. Rev. 1998, 62, 547-585. [PubMed]

97. Gutiérrez, S.; Fierro, F.; Casqueiro, J.; Martín, J.F. Gene organization and plasticity of the beta-lactam genes in different filamentous fungi. Antonie van Leeuwenhoek 1999, 75, 81-94. [CrossRef] [PubMed]

98. Martín, J.F.; Casqueiro, J.; Kosalková, K.; Marcos, A.T.; Gutiérrez, S. Penicillin and cephalosporin biosynthesis: Mechanism of carbon catabolite regulation of penicillin production. Antonie van Leeuwenhoek 1999, 75, 21-31. [CrossRef] [PubMed]

99. Cepeda-García, C.; Domínguez-Santos, R.; García-Rico, R.O.; García-Estrada, C.; Cajiao, A.; Fierro, F.; Martín, J.F. Direct involvement of the CreA transcription factor in penicillin biosynthesis and expression of the $p c b A B$ gene in Penicillium chrysogenum. Appl. Microbiol. Biotechnol. 2014, 98, 7113-7124. [CrossRef] [PubMed]

100. Behmer, C.J.; Demain, A.L. Further studies on carbon catabolite regulation of $\beta$-lactam antibiotic synthesis in Cephalosporium acremonium. Curr. Microbiol. 1983, 8, 107-114. [CrossRef]

101. Brakhage, A.A.; Browne, P.; Turner, G. Regulation of Aspergillus nidulans penicillin biosynthesis and penicillin biosynthesis genes acvA and ipnA by glucose. J. Bacteriol. 1992, 174, 3789-3799. [CrossRef] [PubMed]

102. Revilla, G.; Ramos, F.R.; López-Nieto, M.J.; Alvarez, E.; Martín, J.F. Glucose represses formation of delta-(L-alpha-aminoadipyl)-L-cysteinyl-D-valine and isopenicillin $\mathrm{N}$ synthase but not penicillin acyltransferase in Penicillium chrysogenum. J. Bacteriol. 1986, 168, 947-952. [CrossRef] [PubMed]

103. Lockington, R.A.; Kelly, J.M. Carbon catabolite repression in Aspergillus nidulans involves deubiquitination. Mol. Microbiol. 2001, 40, 1311-1321. [CrossRef] [PubMed]

104. Todd, R.B.; Lockington, R.A.; Kelly, J.M. The Aspergillus nidulans creC gene involved in carbon catabolite repression encodes a WD40 repeat protein. Mol. Gen. Genet. 2000, 263, 561-570. [CrossRef] [PubMed]

105. Zhang, J.; Wolfe, S.; Demain, A.L. Carbon source regulation of the ACV synthetase in Cephalosporium acremonium C-10. Curr. Microbiol. 1989, 18, 361-367. [CrossRef]

106. Tilburn, J.; Sarkar, S.; Widdick, D.A.; Espeso, E.A.; Orejas, M.; Mungroo, J.; Peñalva, M.A.; Arst, H.N., Jr. The Aspergillus PacC zinc finger transcription factor mediates regulation of both acid- and alkaline-expressed genes by ambient pH. EMBO J. 1995, 14, 779-790. [PubMed]

107. Espeso, E.A.; Tilburn, J.; Sánchez-Pulido, L.; Brown, C.V.; Valencia, A.; Arst, H.N., Jr.; Peñalva, M.A. Specific DNA recognition by the Aspergillus nidulans three zinc finger transcription factor PacC. J. Mol. Biol. 1997, 274, 466-480. [CrossRef] [PubMed]

108. Espeso, E.A.; Roncal, T.; Díez, E.; Rainbow, L.; Bignell, E.; Alvaro, J.; Suárez, T.; Denison, S.H.; Tilburn, J.; Arst, H.N., Jr.; et al. On how a transcription factor can avoid its proteolytic activation in the absence of signal transduction. EMBO J. 2000, 19, 719-728. [CrossRef] [PubMed]

109. Peñalva, M.A.; Lucena-Agell, D.; Arst, H.N., Jr. Liaison alcaline: Pals entice non-endosomal ESCRTs to the plasma membrane for $\mathrm{pH}$ signaling. Curr. Opin. Microbiol. 2014, 22, 49-59. [CrossRef] [PubMed]

110. Bussink, H.J.; Bignell, E.M.; Múnera-Huertas, T.; Lucena-Agell, D.; Scazzocchio, C.; Espeso, E.A.; Bertuzzi, M.; Rudnicka, J.; Negrete-Urtasun, S.; Peñas-Parilla, M.M.; et al. Refining the pH response in Aspergillus nidulans: A modulatory triad involving PacX, a novel Zinc binuclear cluster protein. Mol. Microbiol. 2015, 98, 1051-1072. [CrossRef] [PubMed]

111. Barwell, K.J.; Boysen, J.H.; Xu, W.; Mitchell, A.P. Relationship of DFG16 to the Rim101p pH response pathway in Saccharomyces cerevisiae and Candida albicans. Eukaryot. Cell 2005, 4, 890-899. [CrossRef] [PubMed]

112. Rothfels, K.; Tanny, J.C.; Molnar, E.; Friesen, H.; Commisso, C.; Segall, J. Components of the ESCRT pathway, DFG16, and YGR122w are required for Rim101 to act as a corepressor with Nrg1 at the negative regulatory element of the DIT1 gene of Saccharomyces cerevisiae. Mol. Cell. Biol. 2005, 25, 6772-6788. [CrossRef] [PubMed]

113. Calcagno-Pizarelli, A.M.; Negrete-Urtasun, S.; Denison, S.H.; Rudnicka, J.D.; Bussink, H.J.; Múnera-Huertas, T.; Stanton, L.; Hervás-Aguilar, A.; Espeso, E.A.; Tilburn, J.; et al. Establishment of the ambient pH signaling complex in Aspergillus nidulans: PalI assists plasma membrane localization of PalH. Eukaryot. Cell 2007, 6, 2365-2375. [CrossRef] [PubMed] 
114. Herranz, S.; Rodríguez, J.M.; Bussink, H.J.; Sánchez-Ferrero, J.C.; Arst, H.N., Jr.; Peñalva, M.A.; Vincent, O. Arrestin-related proteins mediate $\mathrm{pH}$ signaling in fungi. Proc. Natl. Acad. Sci. USA 2005, 102, 12141-12146. [CrossRef] [PubMed]

115. Hervás-Aguilar, A.; Galindo, A.; Peñalva, M.A. Receptor-independent ambient $\mathrm{pH}$ signaling by ubiquitin attachment to fungal arrestin-like PalF. J. Biol. Chem. 2010, 285, 18095-18102. [CrossRef] [PubMed]

116. Selvig, K.; Alspaugh, J.A. pH response pathways in fungi: Adapting to host-derived and environmental signals. Mycobiology 2011, 39, 249-256. [CrossRef] [PubMed]

117. Vincent, O.; Rainbow, L.; Tilburn, J.; Arst, H.N., Jr.; Peñalva, M.A. YPXL/I is a protein interaction motif recognized by aspergillus PalA and its human homologue, AIP1/Alix. Mol. Cell. Biol. 2003, 23, 1647-1655. [CrossRef] [PubMed]

118. Díez, E.; Alvaro, J.; Espeso, E.A.; Rainbow, L.; Suárez, T.; Tilburn, J.; Arst, H.N., Jr.; Peñalva, M.A. Activation of the Aspergillus PacC zinc finger transcription factor requires two proteolytic steps. EMBO J. 2002, 21, 1350-1359. [CrossRef] [PubMed]

119. Rodríguez-Galán, O.; Galindo, A.; Hervás-Aguilar, A.; Arst, H.N., Jr.; Peñalva, M.A. Physiological involvement in $\mathrm{pH}$ signaling of Vps24-mediated recruitment of Aspergillus PalB cysteine protease to ESCRT-III. J. Biol. Chem. 2009, 284, 4404-4412. [CrossRef] [PubMed]

120. Lucena-Agell, D.; Galindo, A.; Arst, H.N., Jr.; Peñalva, M.A. Aspergillus nidulans Ambient pH signaling does not require endocytosis. Eukaryot. Cell 2015, 14, 545-553. [CrossRef] [PubMed]

121. Hervás-Aguilar, A.; Rodríguez, J.M.; Tilburn, J.; Arst, H.N., Jr.; Peñalva, M.A. Evidence for the direct involvement of the proteasome in the proteolytic processing of the Aspergillus nidulans zinc finger transcription factor PacC. J. Biol. Chem. 2007, 282, 34735-34747. [CrossRef] [PubMed]

122. Suárez, T.; Peñalva, M.A. Characterization of a Penicillium chrysogenum gene encoding a PacC transcription factor and its binding sites in the divergent $p c b A B-p c b C$ promoter of the penicillin biosynthetic cluster. Mol. Microbiol. 1996, 20, 529-540. [CrossRef] [PubMed]

123. Schmitt, E.K.; Kempken, R.; Kück, U. Functional analysis of promoter sequences of cephalosporin C biosynthesis genes from Acremonium chrysogenum: Specific DNA-protein interactions and characterization of the transcription factor PACC. Mol. Genet. Genom. 2001, 265, 508-518.

124. Espeso, E.A.; Tilburn, J.; Arst, H.N., Jr.; Peñalva, M.A. pH regulation is a major determinant in expression of a fungal penicillin biosynthetic gene. EMBO J. 1993, 12, 3947-3956. [PubMed]

125. Yager, L.N. Early developmental events during asexual and sexual sporulation in Aspergillus nidulans. Biotechnology 1992, 23, 19-41. [PubMed]

126. Urnov, F.D. A feel for the template: Zinc finger protein transcription factors and chromatin. Biochem. Cell. Biol. 2002, 80, 321-333. [CrossRef] [PubMed]

127. Teakle, G.R.; Gilmartin, P.M. Two forms of type IV zinc-finger motif and their kingdom-specific distribution between the flora, fauna and fungi. Trends Biochem. Sci. 1998, 23, 100-102. [CrossRef]

128. Laity, J.H.; Lee, B.M.; Wright, P.E. Zinc finger proteins: New insight into structural and functional diversity. Curr. Opin. Struct. Biol. 2001, 11, 39-46. [CrossRef]

129. Marzluf, G.A. Genetic regulation of nitrogen metabolism in the fungi. Microbiol. Mol. Biol. Rev. 1997, 61, 17-32. [PubMed]

130. Kotaka, M.; Johnson, C.; Lamb, H.K.; Hawkins, A.R.; Ren, J.; Stammers, D.K. Structural analysis of the recognition of the negative regulator NmrA and DNA by the zinc finger from the GATA-type transcription factor AreA. J. Mol. Biol. 2008, 381, 373-382. [CrossRef] [PubMed]

131. Li, J.; Pan, Y.; Liu, G. Disruption of the nitrogen regulatory gene AcareA in Acremonium chrysogenum leads to reduction of cephalosporin production and repression of nitrogen metabolism. Fungal Genet. Biol. 2013, 61, 69-79. [CrossRef] [PubMed]

132. Chao, L.Y.; Marletta, M.A.; Rine, J. Sre1, an iron-modulated GATA DNA-binding protein of iron-uptake genes in the fungal pathogen Histoplasma capsulatum. Biochemistry 2008, 47, 7274-7283. [CrossRef] [PubMed]

133. Tudzynski, B. Nitrogen regulation of fungal secondary metabolism in fungi. Front. Microbiol. 2014, 5, 656. [CrossRef] [PubMed]

134. Pfannmüller, A.; Wagner, D.; Sieber, C.; Schönig, B.; Boeckstaens, M.; Marini, A.M.; Tudzynski, B. The general amino acid permease FfGap1 of Fusarium fujikuroi is sorted to the vacuole in a nitrogen-dependent, but Npr1 kinase-independent manner. PLoS ONE 2015, 10, e0125487. [CrossRef] [PubMed] 
135. Ravagnani, A.; Gorfinkiel, L.; Langdon, T.; Diallinas, G.; Adjadj, E.; Demais, S.; Gorton, D.; Arst, H.N., Jr.; Scazzocchio, C. Subtle hydrophobic interactions between the seventh residue of the zinc finger loop and the first base of an HGATAR sequence determine promoter-specific recognition by the Aspergillus nidulans GATA factor AreA. EMBO J. 1997, 16, 3974-3986. [CrossRef] [PubMed]

136. Muro-Pastor, M.I.; Strauss, J.; Ramón, A.; Scazzocchio, C. A paradoxical mutant GATA factor. Eukaryot. Cell 2004, 3, 393-405. [CrossRef] [PubMed]

137. Berger, H.; Pachlinger, R.; Morozov, I.; Goller, S.; Narendja, F.; Caddick, M.; Strauss, J. The GATA factor area regulates localization and in vivo binding site occupancy of the nitrate activator NirA. Mol. Microbiol. 2006, 59, 433-446. [CrossRef] [PubMed]

138. Berger, H.; Basheer, A.; Böck, S.; Reyes-Dominguez, Y.; Dalik, T.; Altmann, F.; Strauss, J. dissecting individual steps of nitrogen transcription factor cooperation in the Aspergillus nidulans nitrate cluster. Mol. Microbiol. 2008, 69, 1385-1398. [CrossRef] [PubMed]

139. Haas, H.; Angermayr, K.; Zadra, I.; Stöffler, G. Overexpression of $n r e B$, a new GATA factor-encoding gene of Penicillium chrysogenum, leads to repression of the nitrate assimilatory gene cluster. J. Biol. Chem. 1997, 272, 22576-22582. [CrossRef] [PubMed]

140. Wong, K.H.; Hynes, M.J.; Todd, R.B.; Davis, M.A. Deletion and overexpression of the Aspergillus nidulans GATA factor AreB reveals unexpected pleiotropy. Microbiology 2009, 155, 3868-3880. [CrossRef] [PubMed]

141. Michielse, C.B.; Pfannmüller, A.; Macios, M.; Rengers, P.; Dzikowska, A.; Tudzynski, B. The interplay between the GATA transcription factors AreA, the global nitrogen regulator and AreB in Fusarium fujikuroi. Mol. Microbiol. 2014, 91, 472-493. [CrossRef] [PubMed]

142. Pfannmüller, A.; Boysen, J.M.; Tudzynski, B. Nitrate Assimilation in Fusarium fujikuroi is controlled by multiple levels of regulation. Front. Microbiol. 2017, 8, 381. [CrossRef] [PubMed]

143. Shen, Y.Q.; Heim, J.; Solomon, N.A.; Wolfe, S.; Demain, A.L. Repression of beta-lactam production in Cephalosporium acremonium by nitrogen sources. J. Antibiot. Tokyo 1984, 37, 503-511. [CrossRef] [PubMed]

144. Feng, B.; Friedlin, E.; Marzluf, G.A. A reporter gene analysis of penicillin biosynthesis gene expression in Penicillium chrysogenum and its regulation by nitrogen and glucose catabolite repression. Appl. Environ. Microbiol. 1994, 60, 4432-4439. [PubMed]

145. Haas, H.; Marzluf, G.A. NRE, the major nitrogen regulatory protein of Penicillium chrysogenum, binds specifically to elements in the intergenic promoter regions of nitrate assimilation and penicillin biosynthetic gene clusters. Curr. Genet. 1995, 28, 177-183. [CrossRef] [PubMed]

146. Menne, S.; Walz, M.; Kück, U. Expression studies with the bidirectional $p c b A B-p c b C$ promoter region from Acremonium chrysogenum using reporter gene fusions. Appl. Microbiol. Biotechnol. 1994, 42, 57-66. [CrossRef] [PubMed]

147. Schjerling, P.; Holmberg, S. Comparative amino acid sequence analysis of the C6 zinc cluster family of transcriptional regulators. Nucleic Acids Res. 1996, 24, 4599-4607. [CrossRef] [PubMed]

148. Platt, A.; Reece, R.J. The yeast galactose genetic switch is mediated by the formation of a Gal4p-Gal80p-Gal3p complex. EMBO J. 1998, 14, 4086-4091. [CrossRef] [PubMed]

149. Mamane, Y.; Hellauer, K.; Rochon, M.H.; Turcotte, B. A linker region of the yeast zinc cluster protein Leu3p specifies binding to everted repeat DNA. J. Biol. Chem. 1998, 273, 18556-18561. [CrossRef] [PubMed]

150. Pan, T.; Coleman, J.E. The DNA binding domain of Gal4 forms a binuclear metal ion complex. Biochemistry 1990, 29, 2023-2029. [CrossRef] [PubMed]

151. Marmostein, R.; Harrison, S.C. Crystal structure of a PPR1-DNA complex: DNA recognition by proteins containing a Zn2Cys6 binuclear cluster. Genes Dev. 1994, 8, 2504-2512. [CrossRef]

152. Anderson, S.F.; Steber, C.M.; Esposito, R.E.; Coleman, J.E. UME6, a negative regulator of meiosis in Saccharomyces cerevisiae, contains a C-terminal Zn2Cys6 binuclear cluster that binds the URS1 DNA sequence in a Zinc-dependent manner. Protein Sci. 1995, 4, 1832-1843. [CrossRef] [PubMed]

153. Marmostein, R.; Carey, M.; Ptashne, M.; Harrison, S.C. DNA recognition by Gal4: Structure of a protein-DNA complex. Nature 1992, 356, 408-414. [CrossRef] [PubMed]

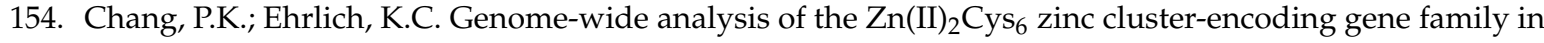
Aspergillus flavus. Appl. Microbiol. Biotechnol. 2013, 97, 4289-4300. [CrossRef] [PubMed]

155. Wolfe, S.A.; Nekludova, L.; Pabo, C.O. DNA recognizion by Cys(2)His(2) zinc finger proteins. Annu. Rev. Biophys. Biomol. Struct. 2000, 29, 183-212. [CrossRef] [PubMed] 
156. Harbison, C.T.; Gordon, D.B.; Lee, T.I.; Rinaldi, N.J.; Macisaac, K.D.; Danford, T.W.; Hannett, N.M.; Tagne, J.B.; Reynolds, D.B.; Yoo, J.; et al. Transcriptional regulatory code of a eukaryotic genome. Nature 2004, 431, 99-104. [CrossRef] [PubMed]

157. Kaestner, K.H.; Knochel, W.; Martinez, D.E. Unified nomenclature for the winged helix/forkhead transcription factors. Genes Dev. 2000, 14, 142-146. [PubMed]

158. Gajiwala, K.S.; Chen, H.; Cornille, F.; Roques, B.P.; Reith, W.; Mach, B.; Burley, S.K. Structure of the winged-helix protein hRFX1 reveals a new mode of DNA binding. Nature 2000, 403, 916-921. [CrossRef] [PubMed]

159. Schmitt, E.K.; Kück, U. The fungal CPCR1 protein, which binds specifically to beta-lactam biosynthesis genes, is related to human regulatory factor X transcription factors. J. Biol. Chem. 2000, 275, 9348-9357. [CrossRef] [PubMed]

160. Schmitt, E.K.; Bunse, A.; Janus, D.; Hoff, B.; Friedlin, E.; Kürnsteiner, H.; Kück, U. Winged helix transcription factor CPCR1 is involved in regulation of beta-lactam biosynthesis in the fungus Acremonium chrysogenum. Eukaryot. Cell 2004, 3, 121-134. [CrossRef] [PubMed]

161. Hoff, B.; Schmitt, E.K.; Kück, U. CPCR1, but not its interacting transcription factor AcFKH1, controls fungal arthrospore formation in Acremonium chrysogenum. Mol. Microbiol. 2005, 56, 1220-1233. [CrossRef] [PubMed]

162. Bugeja, H.E.; Hynes, M.J.; Andrianopoulos, A. The RFX Protein RfxA is an Essential Regulator of Growth and Morphogenesis in Penicillium marneffei. Eukaryot. Cell 2010, 9, 578-591. [CrossRef] [PubMed]

163. Domínguez-Santos, R.; Martín, J.F.; Kosalková, K.; Prieto, C.; Ullán, R.V.; García-Estrada, C. The regulatory factor PcRFX1 controls the expression of the three genes of $\beta$-lactam biosynthesis in Penicillium chrysogenum. Fungal Genet. Biol. 2012, 49, 866-881. [CrossRef] [PubMed]

164. Kaufmann, E.; Müller, D.; Knöchel, W. DNA recognition site analysis of Xenopus winged helix proteins. J. Mol. Biol. 1995, 248, 239-254. [CrossRef]

165. Schmitt, E.K.; Hoff, B.; Kück, U. AcFKH1, a novel member of the forkhead family, associates with the RFX transcription factor CPCR1 in the cephalosporin C-producing fungus Acremonium chrysogenum. Gene 2004, 342, 269-281. [CrossRef] [PubMed]

166. Domínguez-Santos, R.; García-Estrada, C.; Kosalková, K.; Prieto, C.; Santamarta, I.; Martín, J.F. PcFKH1, a novel regulatory factor from the forkhead family, controls the biosynthesis of penicillin in Penicillium chrysogenum. Biochimie 2015, 115, 162-176. [CrossRef] [PubMed]

167. Hicks, J.K.; Shimizu, K.; Keller, N.P. Genetics and biosynthesis of aflatoxins and sterigmatocystin. In The Mycota; Kempken, F., Bennett, J.W., Eds.; Springer-Verlag: Berlin, Germany, 2002; Volume 11, pp. 55-69. ISBN 3-540-42628-0.

168. Bok, J.W.; Keller, N.P. LaeA, a regulator of secondary metabolism in Aspergillus spp. Eukaryot. Cell 2004, 3, 527-535. [CrossRef] [PubMed]

169. Bok, J.W.; Balajee, S.A.; Marr, K.A.; Andes, D.; Nielsen, K.F.; Frisvad, J.C.; Keller, N.P. LaeA, a regulator of morphogenetic fungal virulence factors. Eukaryot. Cell 2005, 4, 1574-1582. [CrossRef] [PubMed]

170. Amaike, S.; Keller, N.P. Distinct Roles for VeA and LaeA in Development and Pathogenesis of Aspergillus flavus. Eukaryot. Cell 2009, 7, 1051-1060. [CrossRef] [PubMed]

171. Lim, F.Y.; Hou, Y.; Chen, Y.; Oh, J.H.; Lee, I.; Bugni, T.S.; Keller, N.P. Genome-based cluster deletion reveals an endocrocin biosynthetic pathway in Aspergillus fumigatus. Appl. Environ. Microbiol. 2012, 78, 4117-4125. [CrossRef] [PubMed]

172. Martín, J.F. Key role of LaeA and velvet complex proteins on expression of $\beta$-lactam and PR-toxin genes in Penicillium chrysogenum: cross-talk regulation of secondary metabolite pathways. J. Ind. Microbiol. Biotechnol. 2017, 44, 525-535. [CrossRef] [PubMed]

173. Dillon, S.C.; Zhang, X.; Trievel, R.C.; Cheng, X. The SET-domain protein superfamily: Protein lysine methyltransferases. Genome Biol. 2005, 6, 227. [CrossRef] [PubMed]

174. Kosalková, K.; García-Estrada, C.; Ullán, R.V.; Godio, R.P.; Feltrer, R.; Teijeira, F.; Mauriz, E.; Martín, J.F. The global regulator LaeA controls penicillin biosynthesis, pigmentation and sporulation, but not roquefortine C synthesis in Penicillium chrysogenum. Biochimie 2009, 91, 214-225. [CrossRef] [PubMed]

175. Palmer, J.M.; Keller, N.P. Secondary metabolism in fungi: Does chromosomal location matter? Curr. Opin. Microbiol. 2010, 13, 431-436. [CrossRef] [PubMed] 
176. Hoff, B.; Kamerewerd, J.; Sigl, C.; Mitterbauer, R.; Zadra, I.; Kürnsteiner, H.; Kück, U. Two components of a velvet-like complex control hyphal morphogenesis, conidiophore development, and penicillin biosynthesis in Penicillium chrysogenum, Eukaryot. Cell 2010, 9, 1236-1250. [CrossRef]

177. Bok, J.W.; Chiang, Y.M.; Szewczyk, E.; Reyes-Dominguez, Y.; Davidson, A.D.; Sanchez, J.F.; Lo, H.C.; Watanabe, K.; Strauss, J.; Oakley, B.R.; et al. Chromatin-level regulation of biosynthetic gene clusters. Nat. Chem. Biol. 2009, 5, 462-464. [CrossRef] [PubMed]

178. Strauss, J.; Reyes-Dominguez, Y. Regulation of secondary metabolism by chromatin structure and epigenetic codes. Fungal Genet. Biol. 2011, 48, 62-69. [CrossRef] [PubMed]

179. Reyes-Dominguez, Y.; Bok, J.W.; Berger, H.; Shwab, E.K.; Basheer, A.; Gallmetzer, A.; Scazzocchio, C.; Keller, N.; Strauss, J. Heterochromatic marks are associated with the repression of secondary metabolism clusters in Aspergillus nidulans. Mol. Microbiol. 2010, 76, 1376-1386. [CrossRef] [PubMed]

180. Patananan, A.N.; Palmer, J.M.; Garvey, G.S.; Keller, N.P.; Clarke, S.G. A novel automethylation reaction in the Aspergillus nidulans LaeA protein generates S-methylmethionine. J. Biol. Chem. 2013, 288, 14032-14045. [CrossRef] [PubMed]

181. Martín, J.; García-Estrada, C.; Kosalková, K.; Ullán, R.V.; Albillos, S.M.; Martín, J.F. The inducers 1,3-diaminopropane and spermidine produce a drastic increase in the expression of the penicillin biosynthetic genes for prolonged time, mediated by the laeA regulator. Fungal Genet. Biol. 2012, 49, 1004-1013. [CrossRef] [PubMed]

182. Bayram, O.; Braus, G.H. Coordination of secondary metabolism and development in fungi: The velvet family of regulatory proteins. FEMS Microbiol. Rev. 2012, 36, 1-24. [CrossRef] [PubMed]

183. Kopke, K.; Hoff, B.; Bloemendal, S.; Katschorowski, A.; Kamerewerd, J.; Kuck, U. Members of the Penicillium chrysogenum velvet complex play functionally opposing roles in the regulation of penicillin biosynthesis and conidiation. Eukaryot. Cell 2013, 12, 299-310. [CrossRef] [PubMed]

184. Bayram, O.; Krappmann, S.; Ni, M.; Bok, J.W.; Helmstaedt, K.; Valerius, O.; Braus-Stromeyer, S.; Kwon, N.J.; Keller, N.P.; Yu, J.H.; et al. VelB/VeA/LaeA complex coordinates light signal with fungal development and secondary metabolism. Science 2008, 320, 1504-1506. [CrossRef] [PubMed]

185. Wiemann, P.; Brown, D.W.; Kleigrewe, K.; Bok, J.W.; Keller, N.P.; Humpf, H.U.; Tudzynski, B. FfVel1 and FfLae1, components of a velvet-like complex in Fusarium fujikuroi, affect differentiation, secondary metabolism and virulence. Mol. Microbiol. 2010, 77, 972-994. [CrossRef] [PubMed]

186. Wu, D.; Oide, S.; Zhang, N.; Choi, M.Y.; Turgeon, B.G. ChLae1 and ChVel1 regulate T-toxin production, virulence, oxidative stress response, and development of the maize pathogen Cochliobolus heterostrophus. PLoS Pathog. 2012, 8, e1002542. [CrossRef] [PubMed]

187. Park, H.S.; Nam, T.Y.; Han, K.H.; Kim, S.C.; Yu, J.H. VelC positively controls sexual development in Aspergillus nidulans. PLoS ONE 2014, 9, e89883. [CrossRef] [PubMed]

188. Dreyer, J.; Eichhorn, H.; Friedlin, E.; Kurnsteiner, H.; Kuck, U. A homologue of the Aspergillus velvet gene regulates both cephalosporin $\mathrm{C}$ biosynthesis and hyphal fragmentation in Acremonium chrysogenum. Appl. Environ. Microbiol. 2007, 73, 3412-3422. [CrossRef] [PubMed]

189. Terfehr, D.; Dahlmann, T.A.; Kück, U. Transcriptome analysis of the two unrelated fungal $\beta$-lactam producers Acremonium chrysogenum and Penicillium chrysogenum: Velvet-regulated genes are major targets during conventional strain improvement programs. BMC Genom. 2017, 18, 272. [CrossRef] [PubMed]

(C) 2018 by the authors. Licensee MDPI, Basel, Switzerland. This article is an open access article distributed under the terms and conditions of the Creative Commons Attribution (CC BY) license (http:/ / creativecommons.org/licenses/by/4.0/). 